\title{
RMetS
}

Royal Meteorological Society

\section{Initiation of deep convection at marginal instability in an ensemble of mesoscale models: a case-study from COPS}

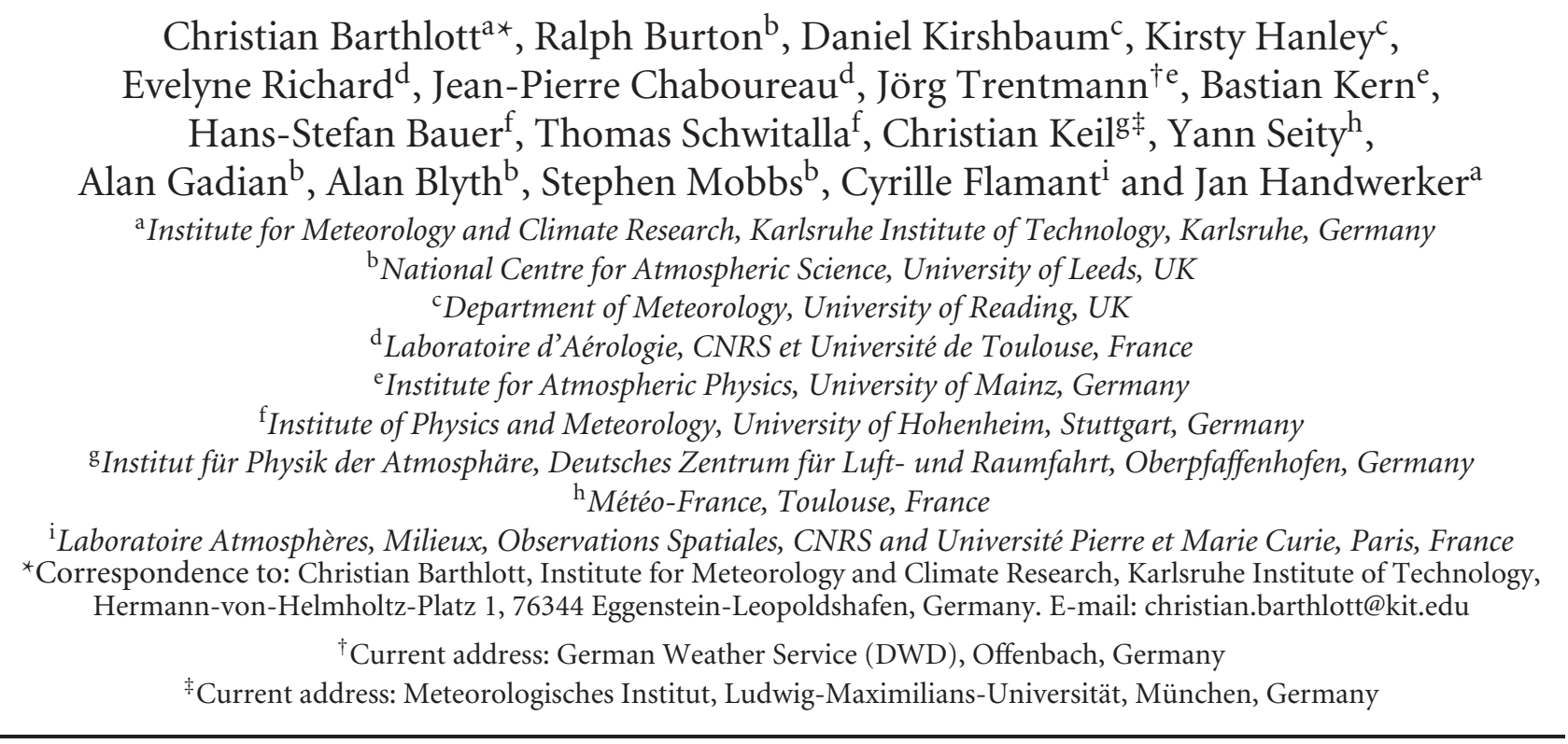

The present study investigates the initiation of precipitating deep convection in an ensemble of convection-resolving mesoscale models. Results of eight different model runs from five non-hydrostatic models are compared for a case of the Convective and Orographically-induced Precipitation Study (COPS). An isolated convective cell initiated east of the Black Forest crest in southwest Germany, although convective available potential energy was only moderate and convective inhibition was high. Measurements revealed that, due to the absence of synoptic forcing, convection was initiated by local processes related to the orography. In particular, the lifting by low-level convergence in the planetary boundary layer is assumed to be the dominant process on that day. The models used different configurations as well as different initial and boundary conditions. By comparing the different model performance with each other and with measurements, the processes which need to be well represented to initiate convection at the right place and time are discussed. Besides an accurate specification of the thermodynamic and kinematic fields, the results highlight the role of boundary-layer convergence features for quantitative precipitation forecasts in mountainous terrain. Copyright (c) 2011 Royal Meteorological Society

Key Words: quantitative precipitation forecast; model intercomparison; UM; WRF; Méso-NH; AROME; COSMO; Black Forest

Received 12 February 2010; Revised 25 May 2010; Accepted 31 August 2010; Published online in Wiley Online Library 6 January 2011

Citation: Barthlott C, Burton R, Kirshbaum D, Hanley K, Richard E, Chaboureau J-P, Trentmann J, Kern B, Bauer H-S, Schwitalla T, Keil C, Seity Y, Gadian A, Blyth A, Mobbs S, Flamant C, Handwerker J. 2011. Initiation of deep convection at marginal instability in an ensemble of mesoscale models: a case-study from COPS. Q. J. R. Meteorol. Soc. 137: 118-136. DOI:10.1002/qj.707

1. Introduction

Quantitative precipitation forecasting (QPF) remains a challenge for state-of-the-art numerical weather prediction
(NWP) models. In particular, the forecast of deep moist convection with weak synoptic forcing is still inadequate for many applications, such as hydrology and flood forecasting. For mountainous regions, several problems for QPF have 
been identified in recent years, e.g. an overestimation of precipitation on the windward side and a phase error in the diurnal cycle (e.g. Chaboureau et al., 2004; Schwitalla et al., 2008). Besides inaccurate initial and boundary conditions, inaccuracies of numerical methods and/or the incomplete description of physical processes influence the performance of NWP models. As was shown by Trentmann et al. (2009), the initial and lateral boundary conditions used for convection-resolving models can have a large impact on the simulated precipitation. Furthermore, for weather regimes with weak synoptic forcing, Stensrud et al. (2000) found that model physics have a stronger impact on QPF than varied initial conditions.

The evolution of deep convection in the absence of largescale forcing requires a sufficient amount of humidity in the lower troposphere, a potentially unstable atmosphere, and a trigger mechanism such as diurnal thermal heating, orographic lifting, or lifting by convergence lines. Byers and Rodebush (1948) were the first to detect the correlation of convective precipitation and the convergence of lowlevel wind. The convergent areas are often restricted to well-defined lines with widths of the order of $1-2 \mathrm{~km}$ (Wilson and Schreiber, 1986). An adequate representation of their strength and ability to lift air parcels is essential for convection initiation in NWP models. However, grid resolution of operational NWP models is on the order of 2-4 km, which makes it difficult to resolve these phenomena correctly.

In orographically complex terrain, thermally driven wind systems like slope and mountain winds may cause convergence zones and hence induce lifting with subsequent cloud formation (Orville, 1965; Raymond and Wilkening, 1980; Barthlott et al., 2006; Kottmeier et al., 2008). The low-mountain region of the Black Forest located in southwest Germany is well known for slope and valley winds (Kossmann and Fiedler, 2000) and often exhibits low QPF quality. This region was selected as the location for the Convective and Orographically-induced Precipitation Study COPS (Wulfmeyer et al., 2008) in summer 2007, with the overall goal to advance the quality of forecasts of orographically induced convective precipitation by fourdimensional observations and modelling of its life cycle. Five supersites with a large number of different observation systems were deployed along a transect through the COPS region, named $\mathrm{V}$ (Vosges), $\mathrm{R}$ (Rhine valley), $\mathrm{H}$ (Hornisgrinde), M (Murg valley), and S (Deckenpfronn near Stuttgart) (Figure 1). Two additional radiosonde stations at Forschungszentrum Karlsruhe (FZK) and Burnhaupt le Bas provided information about the vertical structure of the atmosphere at the northern and southern borders of the COPS region. An overview of the complete set-up of instruments operated is given by Wulfmeyer et al. (2008, 2011).

During the intensive observation period (IOP) $8 \mathrm{~b}$ on 15 July 2007, a single convective cell developed east of the Black Forest crest, although convective available potential energy (CAPE) was only moderate and convective inhibition (CIN) was high. The performance of the multiple operational models on that day was quite variable, ranging from the simulation of shallow clouds without precipitation to a reasonably well simulated single cell with precipitation close to reality. The isolated occurrence of the cell, together with the different model results, were the motivation behind the present model intercomparison study. However, a single case-study cannot be used to conduct a systematic model evaluation or to detect systematic model differences. The goal of this intercomparison is rather to find the reason(s) why some models provide better results than others, to detect if there was a good forecast for the wrong reason, and to determine the processes which have to be well represented in the models to initiate deep convection at the right place and time.

\section{Participating models}

We compare eight different model results from five nonhydrostatic models. The horizontal grid resolution of all models (ranging between 1 and $2.8 \mathrm{~km}$ ) is sufficient enough to resolve at least the coarse modes of deep convection explicitly. The model set-up used by the different groups is given in Table I, sorted by their horizontal grid resolution.

The area of the inner simulation domain with respective highest grid point resolution differs between individual model configurations (Figure 2). The largest inner domains are used by the model with the lowest grid resolution of $2.8 \mathrm{~km}$, the COSMO model (Consortium for Small-scale Modeling, Schättler et al., 2009).

The model with the highest horizontal grid resolution $(1 \mathrm{~km})$ is the Met Office Unified $\operatorname{Model}^{\mathrm{TM}}$ (UM; Davies et al., 2005) operated by the Department of Meteorology at the University of Reading. Initial and boundary data come from a $30 \mathrm{~h}$ global model run starting with the 1200 UTC Met Office global reanalysis of the previous day. Then, three nested domains with 12,4 , and $1 \mathrm{~km}$ resolution were started at 0000 UTC on 15 July. Radiative fluxes or radiance are calculated with the Edwards-Slingo radiation code. An extended mixed-phase cloud scheme after Wilson and Ballard (1999) is used which includes prognostic ice, snow, rain, and graupel. The MOSES 2 land-surface model and a non-local, first-order multi-regime boundary-layer scheme are applied.

The Weather Research and Forecasting Model (WRF; Skamarock et al., 2008) with $1.2 \mathrm{~km}$ grid resolution was used by the National Centre for Atmospheric Science (NCAS), Leeds, hereafter referred to as the WRF_UK, and the Institute of Physics and Meteorology (IPM) of the University of Hohenheim (WRF_DE). WRF_UK was initialised with analyses of the Global Forecast System (GFS), the lateral boundaries being updated every $6 \mathrm{~h}$. The dynamical equations were solved applying a third-order Runge-Kutta time integration scheme. Land use was derived from categories based on the MODIS land-cover classification of the International Geosphere-Biosphere Programme and modified for the Noah land surface model (20 categories). Further physical schemes used are a Morrison two-moment microphysics scheme, a Dudhia (short-wave) and Rapid Radiative Transfer Model (RRTM, long-wave) radiation scheme (called every $2 \mathrm{~min}$ ), a Noah land surface model (four soil levels), a Mellor-Yamada-Janjic turbulent kinetic energy (TKE) scheme, and a Monin-Obukhov (Janjic Eta) surface layer scheme. The nesting was two-way and no cumulus parametrization was used. Results from further sensitivity studies with WRF_UK for that day are given by Burton et al. (2010, pers. comm.)

European Centre for Medium-Range Weather Forecasts (ECMWF) analyses (every $6 \mathrm{~h}$ ) served as initial and boundary conditions for WRF_DE. These analyses had to be transformed from the available model levels to pressure 


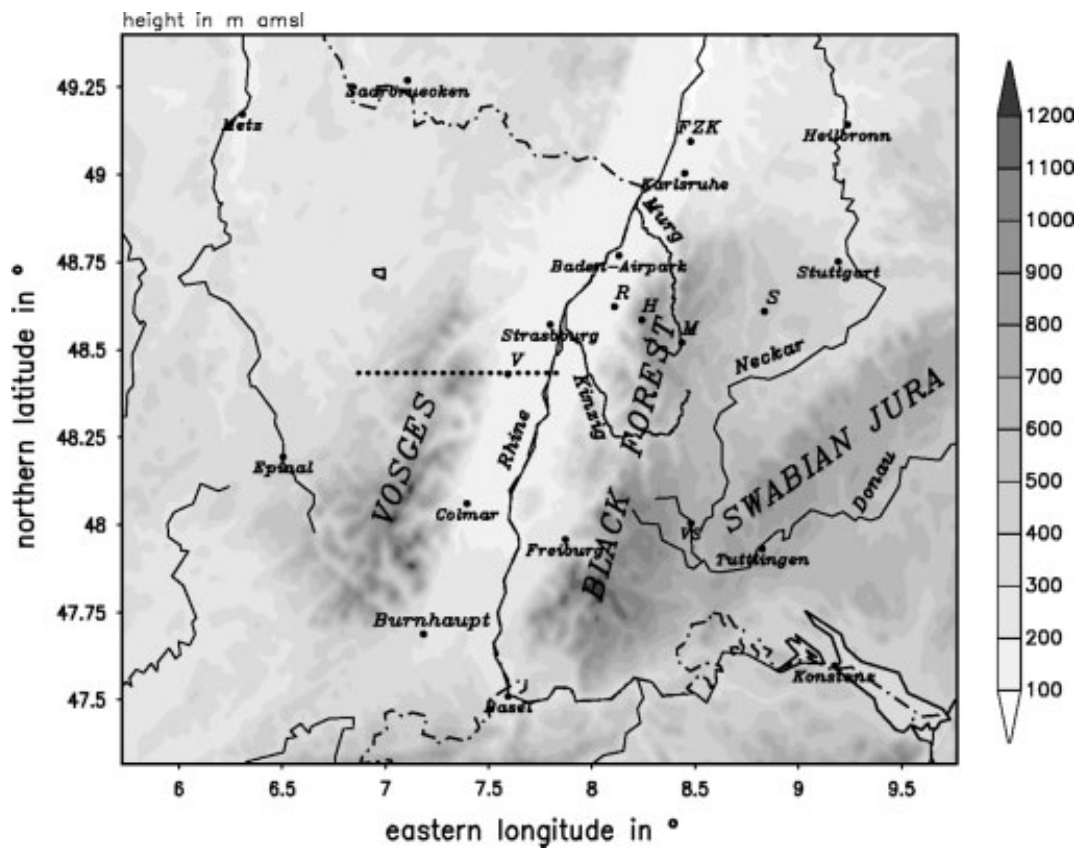

Figure 1. The COPS domain in southwest Germany and eastern France with supersites V, R, H, M, S (see text for explanation) and additional radiosonde stations at Burnhaupt le Bas and Forschungszentrum Karlsruhe (FZK). VS denotes the city of Villingen-Schwenningen. Northern and southern Black Forest are separated by the Kinzig valley. The dashed black line indicates the flight track with airborne lidar measurements of water vapour.

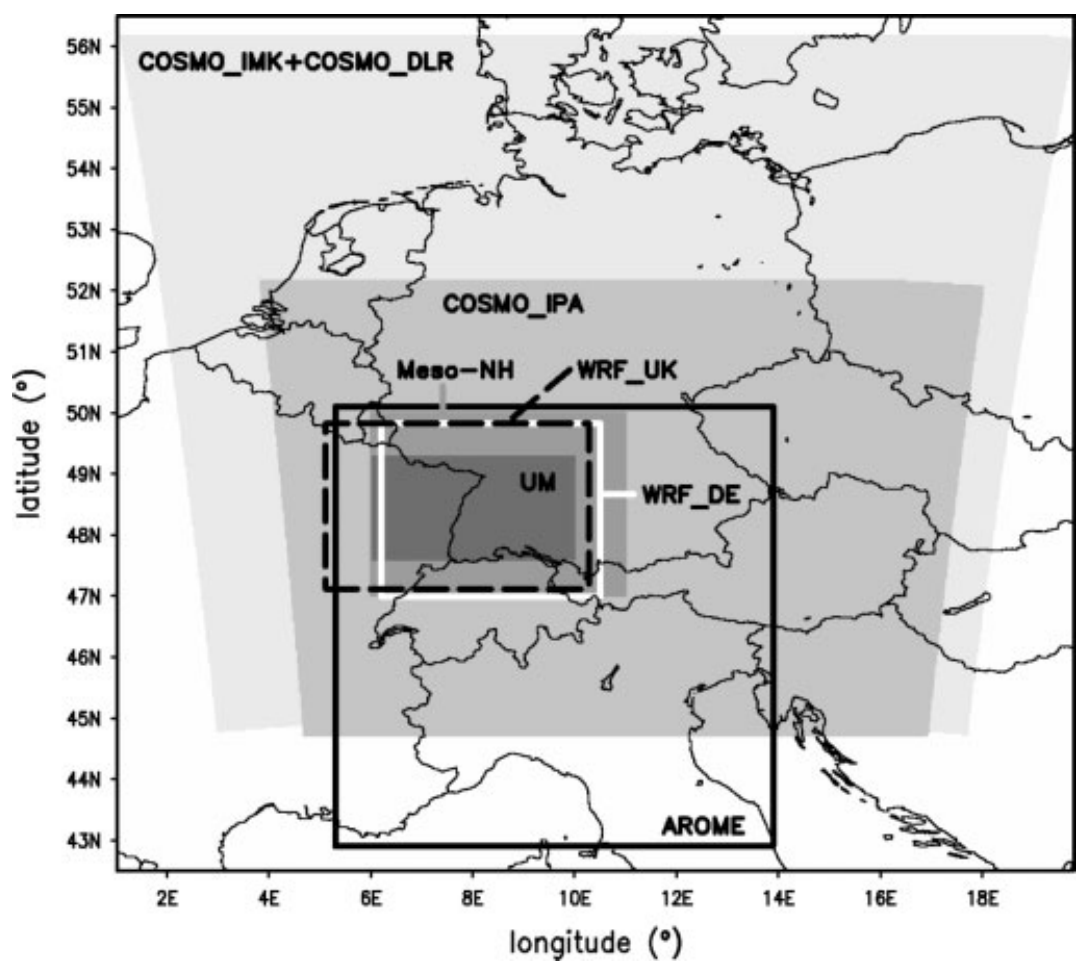

Figure 2. Simulation domains of participating models.

levels. The same microphysics -radiation (here every $5 \mathrm{~min}$ ), and land surface scheme as WRF_UK were used, but for the boundary layer, the Yonsei University scheme was used which is a modification of the Medium-Range Forecast (MRF) scheme to include explicit entrainment fluxes of heat, moisture and momentum, counter-gradient transport of momentum, and different specification of the planetary boundary-layer (PBL) height. The jump in resolution for the two WRF configurations from a global model to $3.6 \mathrm{~km}$ is quite large. However, a recent study by Weisman et al. (2008) showed very satisfactory results based upon
WRF simulation of convection with a similar jump in resolution.

The Laboratoire d'Aérologie (LA) in Toulouse contributed simulations with the Méso-NH model (Lafore et al., 1998). This model is run on three interactive two-way nested domains with horizontal mesh sizes of 32,8 , and $2 \mathrm{~km}$. Initial conditions were derived from ECMWF analyses and the boundary conditions for the outermost domain were interpolated in time from $6 \mathrm{~h}$ ECMWF forecasts. The parametrization schemes include a 1.5-order turbulence scheme, the ECMWF radiation package, the Interactions 
Table I. Participating groups and models.

\begin{tabular}{|c|c|c|c|c|c|c|c|c|}
\hline $\begin{array}{l}\text { Model } \\
\text { name }\end{array}$ & Affiliation* & $\begin{array}{l}\text { Model } \\
\text { version }\end{array}$ & $\begin{array}{l}\text { Initial and } \\
\text { boundary data of } \\
\text { outer domain }^{\S}\end{array}$ & $\begin{array}{l}\text { Inner } \\
\text { domain } \\
(\mathrm{km})^{\dagger}\end{array}$ & $\begin{array}{l}\text { Feedback } \\
\text { between } \\
\text { nests }\end{array}$ & $\begin{array}{l}\text { No. of } \\
\text { grid } \\
\text { points }\end{array}$ & $\begin{array}{l}\text { No. of } \\
\text { levels }\end{array}$ & $\begin{array}{l}\text { Time step } \\
\text { (s) of inner } \\
\text { domain }\end{array}$ \\
\hline UM & DM-UR & $\begin{array}{l}\text { UM } \\
\text { v6.1 }\end{array}$ & $\begin{array}{l}30 \mathrm{~h} \text { global model run } \\
\text { using Met Office } \\
\text { global reanalysis } \\
\text { for } 1200 \text { UTC on } \\
14 \text { July } \\
\rightarrow 12 \mathrm{~km} \mathrm{run}^{\dagger} \rightarrow \\
4 \mathrm{~km} \text { run }\end{array}$ & 1 & 1-way & $300 \times 190$ & 76 & 12 \\
\hline WRF_UK & NCAS-UL & $\begin{array}{l}\text { WRF } \\
\text { v3.1 }\end{array}$ & $\begin{array}{l}24 \mathrm{~h} \text { run with } 3.6 \mathrm{~km} \\
\text { using GFS analyses } \\
\text { every } 6 \mathrm{~h}^{\dagger}\end{array}$ & 1.2 & 2-way & $300 \times 240$ & 50 & 6 \\
\hline WRF_DE & IPM-UH & $\begin{array}{l}\text { WRF } \\
\text { v3.1 }\end{array}$ & $\begin{array}{l}24 \mathrm{~h} \text { run with } 3.6 \mathrm{~km} \\
\text { using ECMWF } \\
\text { analyses every } 6 \mathrm{~h}^{\dagger}\end{array}$ & 1.2 & 1-way & $250 \times 250$ & 50 & 5 \\
\hline Méso-NH & LA-CNRS-UT & Méso-NH & $8 \mathrm{~km} \mathrm{run}^{\dagger}$ & 2 & 2-way & $192 \times 180$ & 50 & 3.75 \\
\hline AROME & $\mathrm{M}-\mathrm{F}$ & AROME & 10 km ALADIN-France & 2.5 & 1-way & $400 \times 320$ & 41 & 60 \\
\hline COSMO_DLR & IPA-DLR & $\begin{array}{l}\text { COSMO } \\
\mathrm{v} 4.8\end{array}$ & $\begin{array}{l}7 \mathrm{~km} \text { COSMO-LEPS } \\
\text { forecast (nested on } \\
\text { selected members } \\
\text { of ECMWF EPS) }\end{array}$ & 2.8 & 1-way & $421 \times 461$ & 50 & 25 \\
\hline COSMO_IPA & IPA-UM & $\begin{array}{l}\text { COSMO } \\
\mathrm{v} 4.3\end{array}$ & $\begin{array}{l}7 \mathrm{~km} \text { COSMO forecast } \\
\text { based on ECMWF } \\
\text { analyses for } 1800 \text { UTC } \\
\text { on } 14 \text { July }\end{array}$ & 2.8 & 1-way & $351 \times 375$ & 50 & 30 \\
\hline COSMO_IMK & IMK-KIT & $\begin{array}{l}\text { COSMO } \\
\text { v } 4.0\end{array}$ & $\begin{array}{l}7 \mathrm{~km} \text { COSMO-EU } \\
\text { analyses }\end{array}$ & 2.8 & 1-way & $421 \times 461$ & 50 & 30 \\
\hline
\end{tabular}

*Abbreviated affiliations are: DM-UR (Department of Meteorology, University of Reading, UK),

NCAS-UL (National Centre for Atmospheric Science, University of Leeds, UK),

IPM-UH (Institute of Physics and Meteorology, University of Hohenheim, Germany),

LA-CNRS-UT (Laboratoire d'Aérologie, CNRS et Université de Toulouse, France),

M-F (Météo-France, Toulouse, France),

IPA-DLR (Institut für Physik der Atmosphäre, Deutsches Zentrum für Luft- und Raumfahrt, Oberpfaffenhofen,

Germany), IPA-UM (Institut für Physik der Atmosphäre, University of Mainz, Germany),

IMK-KIT (Institute for Meteorology and Climate Research, Karlsruhe Institute of Technology, Germany).

${ }^{\dagger}$ Initialised at 0000 UTC on 15 July.

${ }^{\S}$ Grid resolutions of global models: $\mathrm{UM} 0.5625^{\circ} \times 0.375^{\circ}$, ECMWF $0.225^{\circ}$, and GFS $0.5^{\circ}$.

Soil-Biosphere-Atmosphere (ISBA) surface scheme, and a mixed-phase bulk microphysics scheme for cloud, rain, ice, snow, graupel, and hail. Deep and shallow convection schemes were used for the 32 and $8 \mathrm{~km}$ models only. Results from further sensitivity studies with Méso-NH for that day are given by Richard et al. (2011).

Model simulations using the AROME (Application of Research to Operational at MEsoscale) model were conducted by Météo-France with a $2.5 \mathrm{~km}$ grid mesh (Bouttier, 2009). The physical package used is extracted from the Méso-NH research model and has been interfaced with the non-hydrostatic version of the ALADIN software. The model is coupled every $3 \mathrm{~h}$ with the ALADIN-France $10 \mathrm{~km}$ operational model. AROME also has its own mesoscale data assimilation system based on $3 \mathrm{D}-\mathrm{V}$ ar with a $3 \mathrm{~h}$ rapid update cycle. The physical parametrizations of AROME are identical to those of Méso-NH, except that hail is not accounted for in the microphysical scheme and the radiation code is called every $15 \mathrm{~min}$ instead of $30 \mathrm{~min}$.

Three different set-ups of the COSMO model (Schättler et al., 2009) with $2.8 \mathrm{~km}$ grid resolution complement the present study. In this model system, shallow convection was parametrized using a modified Tiedtke scheme. A sixclass graupel scheme was used for microphysics, a TKE scheme for turbulence, and a third-order Runge-Kutta method for the dynamics. At the Deutsches Zentrum für Luft- und Raumfahrt (DLR) the COSMO model version 4.8 (hereafter referred to as COSMO_DLR) was nested into ten representative members of the COSMO-LEPS ensemble prediction system (Molteni et al., 2001). A realistic member was selected for the present intercomparison by visual inspection and application of the displacement and amplitude score (DAS; Keil and Craig, 2009) on precipitation amounts. The model simulations at the Institute for Atmospheric Physics (IPA) of the University of 
Mainz were conducted using model version 4.3 (hereafter referred to as the COSMO_IPA). It was initialised with COSMO forecasts at $7 \mathrm{~km}$ grid resolution based on ECMWF analyses starting from 1800 UTC of the previous day. The Institute for Meteorology and Climate Research (IMK) at the Karlsruhe Institute of Technology used COSMO model version 4.0 (hereafter referred to as the COSMO_IMK). Initial and boundary data were taken from COSMOEU analyses. COSMO_DLR and COSMO_IMK were run on the same model domain, whereas the domain used in the COSMO_IPA simulations was somewhat smaller (Figure 2). Furthermore, the soil had two levels only, whereas COSMO_DLR and COSMO_IMK used seven active soil layers. The radiation scheme was called every time step for COSMO_IPA, and the other configurations used intervals of $15 \mathrm{~min}$. The topographic correction of radiation due to the terrain slope angle, sky view factor, and shadowing (Müller and Scherer, 2005; Buzzi, 2008) were included by COSMO_IPA only. Both COSMO_DLR and COSMO_IPA simulations were conducted with recently changed new tuning parameters of the maximal turbulent length-scale, the critical value for normalised oversaturation, and the cloud cover at saturation. However, the results at IMK were obtained with an older configuration comparable to the one from Barthlott et al. (2010). They explored the potential benefit of a higher grid resolution of $1 \mathrm{~km}$ compared to $2.8 \mathrm{~km}$ for the representation of low-level convergence on that day by using COSMO-EU forecasts (operational $7 \mathrm{~km}$ COSMO configuration at the Deutscher Wetterdienst, DWD) instead of analyses as initial and boundary data. The general model performance was not affected by the change of initial and boundary data.

In this study, all model runs of the respective inner domains were initialised at the same time (0000 UTC on July 15). However, not all driving models had the same initialisation time (Table I). A data assimilation technique was used by AROME (3D-Var) only. The temporal resolution for the model output was every 15 min for AROME, Méso-NH, and WRF_UK, whereas a variable temporal output of $30 \mathrm{~min}$ (0000-1200 UTC and 1700-2400 UTC) and $15 \mathrm{~min}$ (1200-1700 UTC) was used for the UM, WRF_DE, and the three COSMO simulations. Furthermore, it must be stated that the results of AROME and Méso-NH come from the operational run during the COPS field phase, whereas the remaining model simulations were performed at a later date specifically for the purposes of this intercomparison. For the references to the physical schemes and dynamics, we refer to the overview literature of each model mentioned above.

\section{Observations}

During COPS IOP 8b on 15 July 2007, a single convective cell developed east of the Black Forest crest. On this day, the COPS area was located in the transition zone between an eastern European ridge, stretching from the Mediterranean Sea to Poland and a high-amplitude eastern Atlantic trough. GFS analyses showed that only minimal advection of positive vorticity in the upper troposphere and warm air in the lower troposphere prevailed throughout the whole day. As a consequence, the large-scale forcing was of minor importance. The temporal evolution of convection and the identified trigger mechanism will be summarised in the

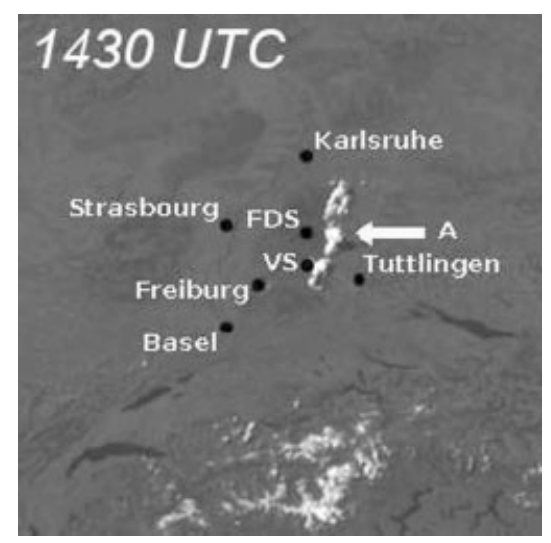

Figure 3. MSG visible image of the COPS region. $\mathrm{A}$ is the largest convection cell. FDS and VS denote the cities of Freudenstadt and VillingenSchwenningen, respectively.

following paragraphs. A detailed analysis is given by Kalthoff et al. (2009).

By using Meteosat Second Generation (MSG) Rapid Scans, first clouds were detected starting from 1200 UTC to the north and south of Freudenstadt (Figure 3). Until 1430 UTC, two more-or-less connected north-south oriented shallow cloud bands moved slightly to the east. From these cloud bands, three isolated deep convective cells developed in the next hour. As was pointed out by Aoshima et al. (2008), the time of convection initiation (CI) of the largest cell A (Figure 3) was at 1430 UTC. The two smaller cells developed in the area of Pforzheim (Figure 4) and west of Villingen-Schwenningen (1450 UTC, not shown) reaching a height of around $8 \mathrm{~km}$ only. The most intense cell A evolved rapidly within $30 \mathrm{~min}$ to a mature cumulonimbus cloud up to a height of $12 \mathrm{~km}$ above ground level (agl), accompanied by heavy precipitation, hail, and lightning (Kottmeier et al., 2008). After around 1515 UTC, the anvil cloud was detached from the original cloud base and then advected to the northeast with the mean wind. The COPS area was again free of clouds after 1730 UTC.

The Stueve diagrams of two radiosonde profiles before the evolution of deep convection (1100-1130 UTC) show a warm, but dry air mass in the Rhine valley and east of the northern Black Forest summit, with a PBL-capping inversion and a weak inversion at about $2200 \mathrm{~m}$ above mean sea level (amsl) (Figure 5).

Some thermodynamic variables of three radiosonde stations are given in Table II. Large values of CIN inhibited the evolution of deep convection; CAPE was moderate only. The convective condensation level (CCL) was high and above the weak inversion at $2200 \mathrm{~m}$ amsl. The level of free convection (LFC) could not be reached through buoyancy only, because the convective temperature $T_{\mathrm{c}}$ was not reached by the near-surface air temperature $T_{0}$.

According to Kalthoff et al. (2009), the formation of convective clouds in the northern Black Forest was due to an optimal superposition of two convergence zones: a mesoscale convergence zone between a surface high east of the Black Forest and a surface low approaching the investigation area from the west, and a convergence zone along the mountain crest due to slope and valley winds. When the mesoscale convergence zone reached the Black Forest crest, strong updraughts with subsequent cloud formation were observed at the time of superposition. 

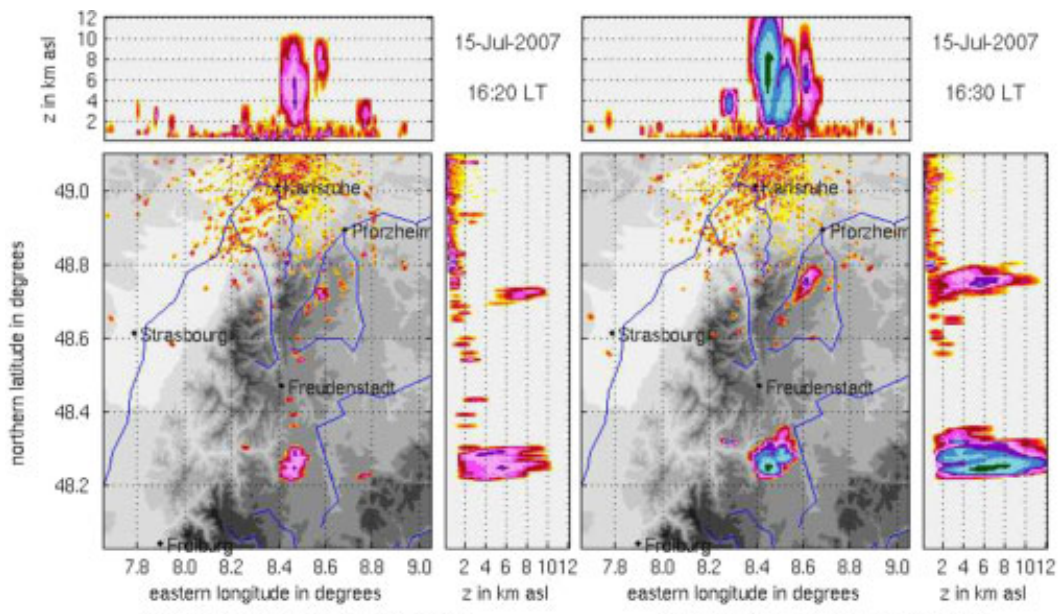

(a) Radar reflectivity 1420 UTC

(b) Radar reflectivity 1430 UTC
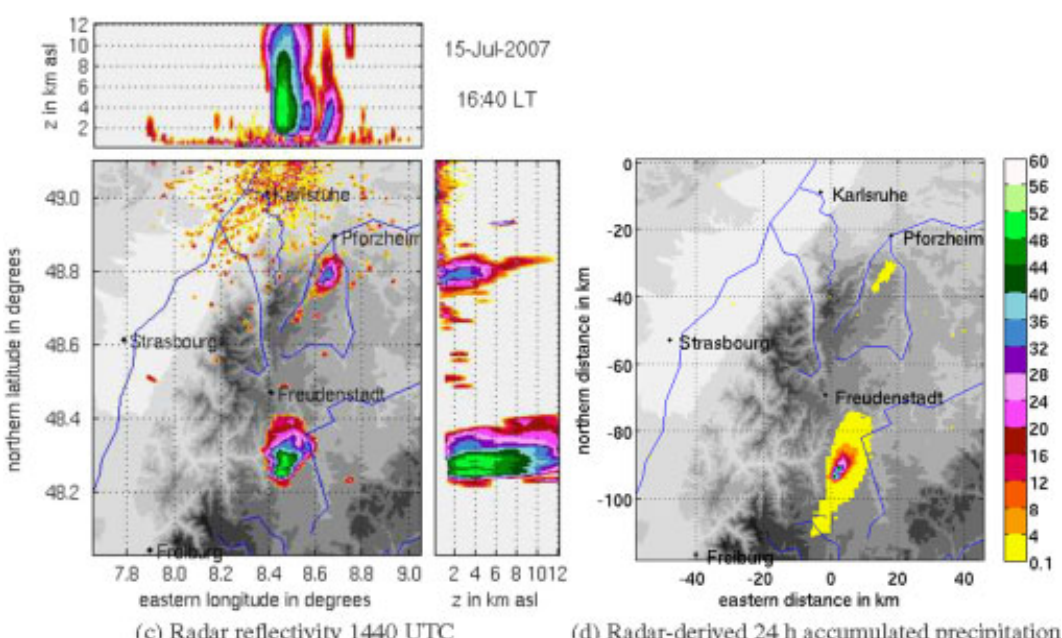

(d) Radar-derived $24 \mathrm{~h}$ accumulated precipitation

Figure 4. Radar reflectivity (dBZ) measured by the IMK C-band radar positioned at FZK at (a) 1420 UTC, (b) 1430 UTC and (c) 1440 UTC, from the first distinct radar echo to the mature cumulonimbus cloud. (d) shows the derived $24 \mathrm{~h}$ accumulated precipitation (mm). This figure is available in colour online at wileyonlinelibrary.com/journal/qj

(a)

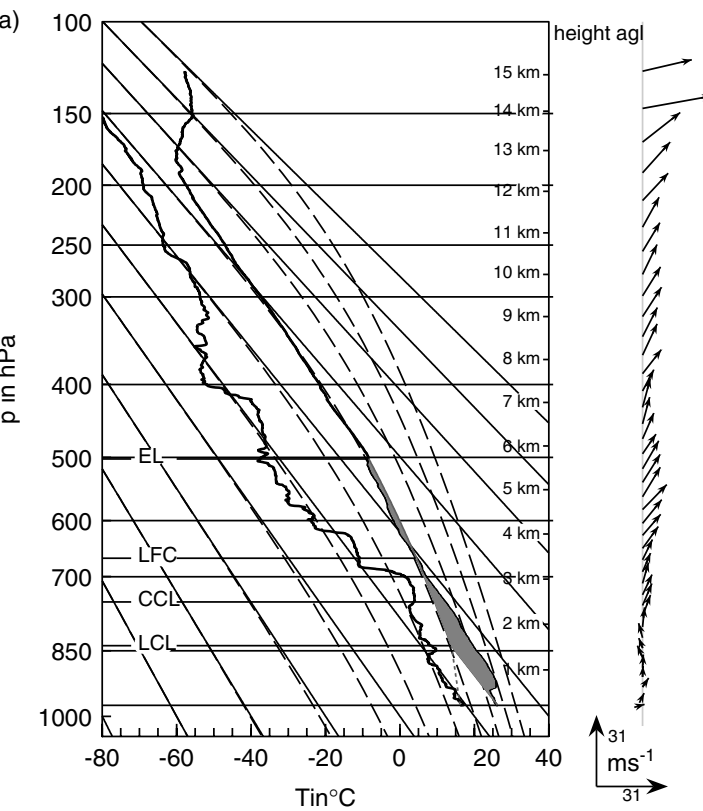

(b)

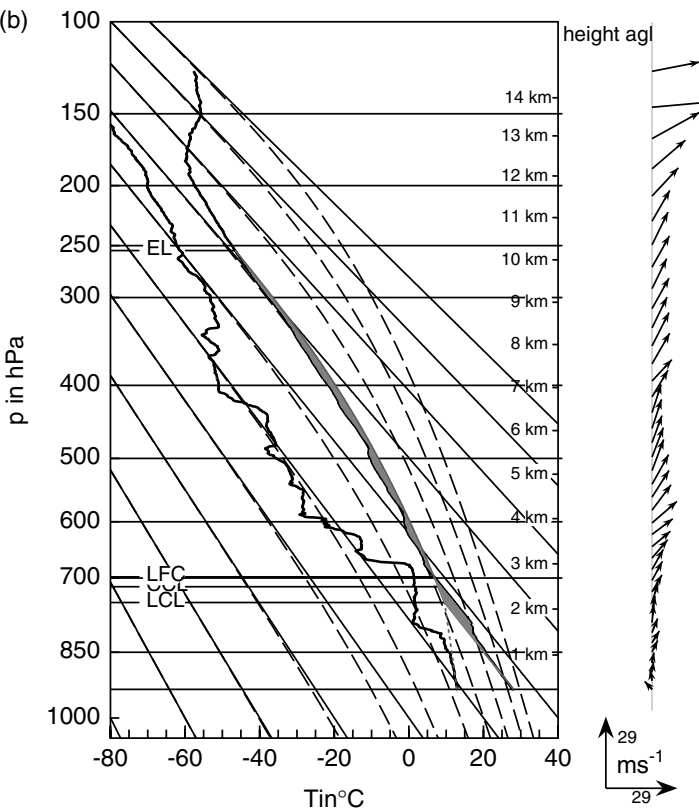

Figure 5. Radiosonde profiles of temperature, dewpoint temperature, and horizontal wind vectors at (a) supersite $\mathrm{R}$ (Achern, Rhine valley, $140 \mathrm{~m}$ amsl) at 1100 UTC and (b) supersite M (Heselbach, Murg valley, $511 \mathrm{~m}$ amsl) at 1130 UTC. The grey shaded areas below and above the LFC represent CIN and CAPE, respectively. 
Table II. Thermodynamic variables calculated from vertical soundings around 1100 UTC by lifting a parcel that reflects the mean values of the temperature and moisture in the lowest $50 \mathrm{hPa}$.

\begin{tabular}{lccc}
\hline Station & $\begin{array}{c}\text { FZK } \\
(110 \mathrm{~m} \mathrm{amsl})\end{array}$ & $\begin{array}{c}\text { Supersite R } \\
(140 \mathrm{~m} \mathrm{amsl})\end{array}$ & $\begin{array}{r}\text { Supersite M } \\
(511 \mathrm{~m} \mathrm{amsl})\end{array}$ \\
\hline $\mathrm{CAPE}^{a}$ & 358 & 86 & 414 \\
$\mathrm{CIN}^{a}$ & 94 & 219 & 46 \\
$\mathrm{CCL}^{b}$ & 2751 & 2495 & 2495 \\
$\mathrm{LCL}^{b}$ & 2167 & 1532 & 2147 \\
$\mathrm{LFC}^{b}$ & 3134 & 3462 & 2717 \\
$\mathrm{EL}^{b}$ & 10451 & 5697 & 10215 \\
$T_{\mathrm{c}}{ }^{c}$ & 35.6 & 34.4 & 31.0 \\
$T_{0}{ }^{c}$ & 30.6 & 26.3 & 28.1 \\
\hline
\end{tabular}

Units: ${ }^{a} \mathrm{~J} \mathrm{~kg}^{-1} ;{ }^{b} \mathrm{~m} \mathrm{agl} ;{ }^{c}{ }^{\circ} \mathrm{C}$.

The updraughts penetrated the PBL-capping inversion and reached the level of free convection.

However, the main thunderstorm was initiated in the transition zone from the northern to southern Black Forest, east of the Kinzig valley (Figure 4). In that area, a convergence zone northeast of Freiburg (detected by the DWD radar positioned on the Feldberg mountain -not shown -around 1100 UTC) moved slowly towards the east (Barthlott et al., 2010). The strong spatial correlation of the convergence with subsequent cloud formation highly suggests that lifting along this convergence line was the key trigger mechanism of the observed convective cell on that day. From the measurements, it is not obvious whether the northern and southern convergence lines were connected. For information about the pre-convective atmosphere and the moisture distribution with emphasis on data exploitation of lidars, we refer to Behrendt et al. (2011).

\section{Model results}

At first, the model performance regarding the existence of simulated convective precipitation is presented. Mean values of near-surface temperature and moisture at 0000 and 1200 UTC are then used to investigate differences in the initial field and their different evolutions over time. In order to detect possible reasons why some models were more successful than others in reproducing the observed storm, the following sections compare several convectionrelated parameters in the model results with observations. Furthermore, the question whether there was a good forecast for the wrong reason will be investigated.

\subsection{Convective precipitation}

Only five of the model runs succeed in simulating convective precipitation in the COPS area (Figure 6). The UM simulates precipitation up to $15 \mathrm{~mm}$ near Villingen-Schwenningen, which is $0.3^{\circ}$ too far south when compared with observations (Figure 4). However, large amounts of precipitation are simulated in the northern part of the Vosges mountains and also to the east of Karlsruhe, where no precipitation was observed.

With the exception of two precipitation areas at the southern borders of the simulation domain, the WRF_UK run shows precipitation induced by a single convective cell east of Villingen-Schwenningen and two smaller amounts of rain east of the northern Black Forest crest. A smaller thunderstorm in that area (south of Pforzheim, Figure 4) was observed, documenting the good capture of convective activity of WRF_UK even if the main cell is simulated too far south.

Approximately at the same location, the Méso-NH model simulates convective precipitation with a slightly larger horizontal extent. No precipitation is simulated in other areas of the model domain. Similar results but with a higher rain amount and at a slightly higher latitude are provided by AROME. The area of precipitation simulated by this model is the closest to the observed storm of all model runs. Furthermore, the amount of maximum precipitation $(30-40 \mathrm{~mm})$ corresponds the most to the radar-derived accumulated precipitation $(\approx 40-44 \mathrm{~mm})$. It must be stated that radar is not a measuring instrument in a quantitative sense. In particular, the existence of hail increases the uncertainty in radarderived precipitation due to the differing reflectivities of hail and rain droplets. However, as a qualitative measure and to detect the geographical extent of the observed precipitation, radar measurements will be used in this study. Furthermore, due to its small horizontal extent, convective precipitation was not measured by the surface rain-gauge network.

COSMO_DLR simulates a number of convective cells east of the northern Black Forest, but only a small amount of rain to the south of Villingen-Schwenningen. A reason for the high number of convective cells could be the use of a semi-Lagrangian advection scheme for the moisture variables instead of an Euler-forward advection scheme after Bott (1989) used in the two other COSMO configurations. Because of numerical instabilities in the simulations of some wintertime conditions, the DWD introduced the semiLagrangian advection scheme in November 2008. However, due to the existence of unrealistically large amounts of rainfall in situations with deep moist convection, the Bott scheme was applied again in spring 2009. The other two COSMO configurations (COSMO_IPA and COSMO_IMK) as well as WRF_DE did not simulate convective precipitation in the IOP analysed.

The temporal evolution of spatially integrated precipitation for an area around the main cell $(52 \times 78 \mathrm{~km})$ and in the remaining COPS area $(180 \times 178 \mathrm{~km})$ is given in Figure 7 . Radar-derived precipitation larger than 1 litre is present from 1420 to 1520 UTC. In the simulations with the UM, precipitation starts too early (1000 UTC, small amounts already around 0600 UTC), the rain duration is too long $(5.75 \mathrm{~h})$, and significant amounts of precipitation are simulated outside the box surrounding the main convective cell. Hence, the UM overestimates the convective activity during the selected IOP.

The onset of precipitation in WRF_UK is only 25 min later than observed, the maximum rain intensity is $35 \mathrm{~min}$ too late, and the rain lasts $1.25 \mathrm{~h}(0.25 \mathrm{~h}$ longer than observed $)$. Even if the accumulated precipitation over time (133 litre) is smaller than observed (1160 litre, Table III), it can be stated that WRF_UK succeeds well in reproducing the observed convective cell, at least regarding its timing and location.

Both the timing of maximum rain intensity and the onset of precipitation are well captured by Méso-NH. 

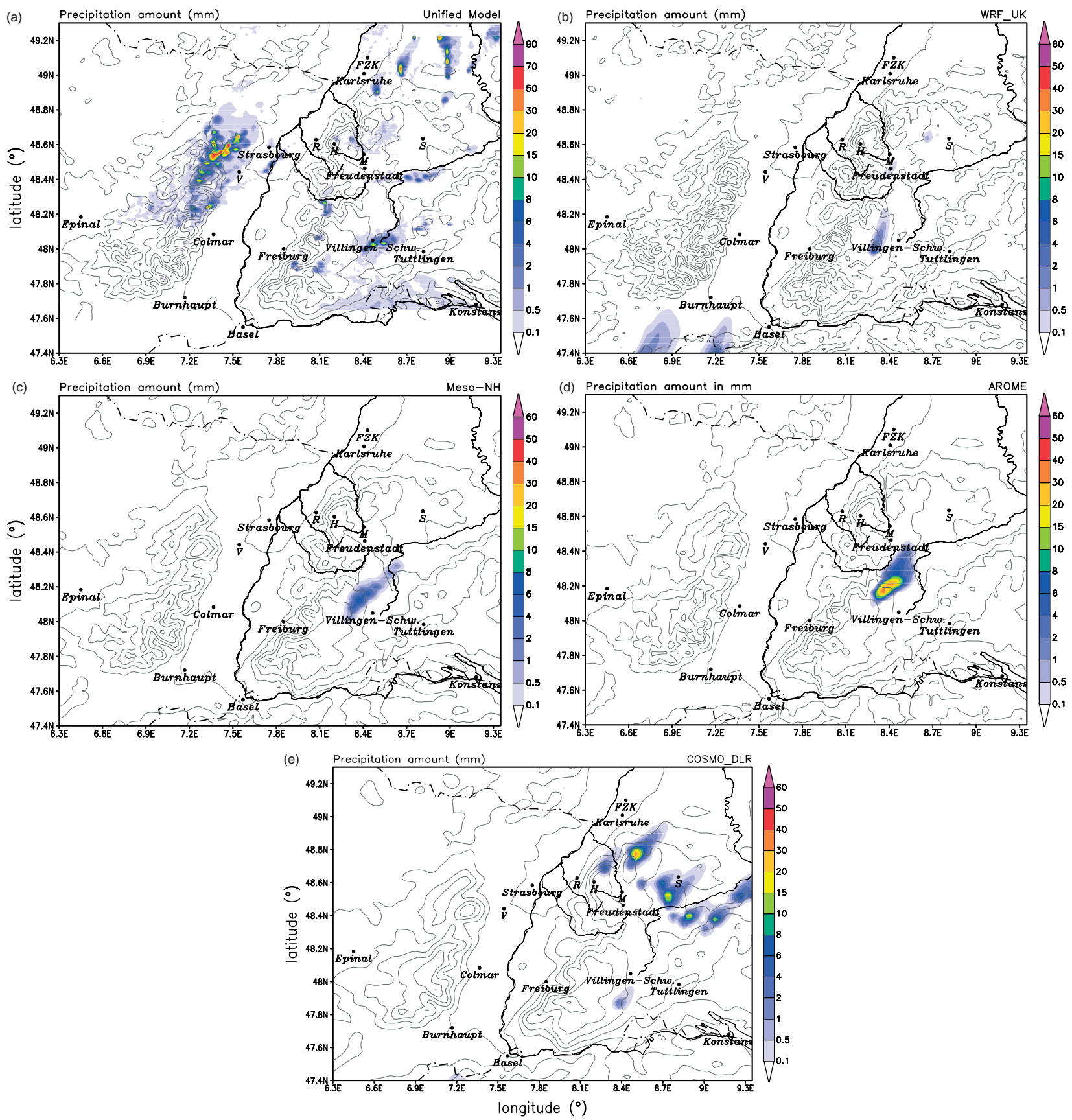

Figure 6. Simulated $24 \mathrm{~h}$ accumulated precipitation for the model runs with convective precipitation $>0.5 \mathrm{~mm}$ : (a) UM, (b) WRF_UK, (c) Méso-NH, (d) AROME, and (e) COSMO_DLR. This figure is available in colour online at wileyonlinelibrary.com/journal/qj

Table III. $24 \mathrm{~h}$ accumulated precipitation (litres) for the inner box of the main convective cell.

\begin{tabular}{cccccc}
\hline Radar & UM & $\begin{array}{c}\text { WRF } \\
\text { UK }\end{array}$ & $\begin{array}{c}\text { Méso } \\
\text {-NH }\end{array}$ & AROME & $\begin{array}{c}\text { COSMO } \\
\text { DLR }\end{array}$ \\
\hline 1160 & 786 & 133 & 195 & 605 & 36 \\
\hline
\end{tabular}

The accumulated rain amount, however, is somewhat smaller (195 litre) than observed. The closest simulation to the measured accumulated precipitation is by AROME (605 litre). In this model, the onset of rain is simultaneous with the observations; maximum rain intensity is only 20 min later than the observed time, but precipitation ends about $1 \mathrm{~h}$ later than in reality. The precipitation amount of COSMO_DLR is too low and significant amounts of rainfall are simulated outside the area of the main cell.

Summarising the main findings concerning the simulated convective precipitation, it can be stated that WRF_UK, Méso- $\mathrm{NH}$, and AROME succeed well in reproducing the convective activity on the day analysed. The UM overestimates the convective activity in other domains of the COPS area and produces too long-lasting precipitation in the area of the main cell. COSMO_DLR simulates a comparatively small amount of rain in the area of the main cell, but also overestimates the convective activity in other regions. Finally, the models WRF_DE, COSMO_IPA, and COSMO_IMK did not simulate convective precipitation larger than $0.5 \mathrm{~mm}$. 


\subsection{Model topography and temporal evolution of area- averaged near-surface variables}

The horizontal grid resolution of the participating models varies between 1 and $2.8 \mathrm{~km}$. In order to analyse possible differences of the representation of the topography in the models, their topography values were classified in steps of $20 \mathrm{~m}$ for the domain displayed in Figure 6. The frequency distribution (Figure 8) shows that all models have the same lowest elevation (class $80-100 \mathrm{~m}$ ) and the same dominant elevation (class $240-260 \mathrm{~m}$ ). The maximum class varies between $1200-1220 \mathrm{~m}$ for the COSMO model and 1300-1320 m for both WRF configurations. However, the number of points in these classes are very low $(\leq 7)$. It can therefore be concluded that, despite the different grid resolutions, the orography is represented similarly in all model configurations, and differences in model results are not attributable to different model representations of the orography.

An analysis of the $2 \mathrm{~m}$ temperature in the afternoon revealed differences of up to $10 \mathrm{~K}$ simulated with Méso-NH and COSMO_IMK in the Rhine valley (not shown). To study the initial conditions of the models and the temporal evolution of near-surface temperature and humidity, mean values at 0000 and 1400 UTC for the above-mentioned domain were calculated. The process of a model adjusting to its forcing (model spin-up) can severely bias the results from the earliest part of the runs. However, the analysis of interpolated fields at 0000 UTC on the respective highresolved model grid is still a more appropriate approach than the analysis of the forcing model on a coarser grid. The results in Figure 9 show that the mean temperature at initialisation time varied between $17.2^{\circ} \mathrm{C}$ (WRF_UK) and $21.3^{\circ} \mathrm{C}$ (COSMO_DLR). In the afternoon, differences become slightly smaller (COSMO_DLR: $28.1^{\circ} \mathrm{C}$; AROME: $31.9^{\circ} \mathrm{C}$ ). Specific humidity varies from $10 \mathrm{~g} \mathrm{~kg}^{-1}$ (UM) to $12.2 \mathrm{~g} \mathrm{~kg}^{-1}$ (Méso-NH) at 0000 UTC and shows greater differences at 1400 UTC between the individual model runs (COSMO_IPA: $11.3 \mathrm{~g} \mathrm{~kg}^{-1}$, Méso-NH: $15 \mathrm{~g} \mathrm{~kg}^{-1}$ ). Due to the temperature increase in the course of the day, relative humidity is reduced from values between 67 and $85 \%$ to 39-59\%. The variable increase and decrease rates displayed on the right-hand side of Figure 9 reflect the fact that besides different initial and boundary data, the differing model physics play a major role, e.g. COSMO_DLR starts with the highest near-surface temperature, but the mean values in the afternoon are the lowest of all model configurations. Another finding evident from Figure 9 is the lack of agreement between models which successfully simulated the convective event of the day. Méso-NH and AROME did reveal quite similar results as far as convective precipitation is concerned. Whereas the latter has the highest near-surface temperature with the driest relative humidity, Méso- $\mathrm{NH}$ reveals the highest relative humidity and second lowest temperature of all model configurations. Consequently, thermal forcing must have played a large role for AROME, whereas the large amount of low-level moisture could have increased the PBL's total energy (described by the moist static energy) for Méso-NH, which is expected to result in an increase of CAPE.

As the calculated mean values for the whole COPS domain are not representative for small-scale initiation processes, the conditions in the surroundings of the convective storm will be analyzed in the following sections.
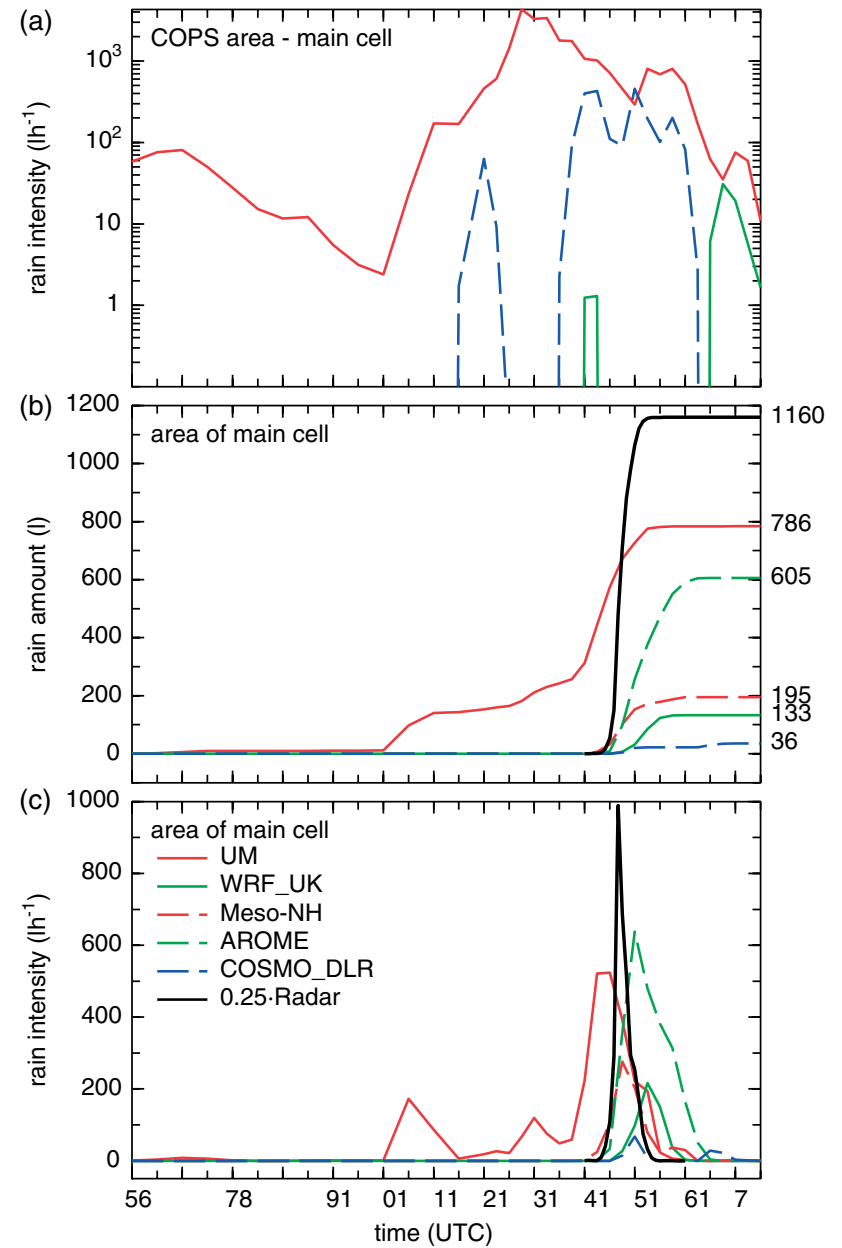

Figure 7. Spatially integrated (a) rain intensity over the COPS area outside the main cell, (b) cumulative rain amount inside a box surrounding the area of the convective cell, and (c) rain intensity inside this box. In (c), the radarderived intensity was divided by 4 to allow better clarity of the other curves. This figure is available in colour online at wileyonlinelibrary.com/journal/qj

\subsection{Time series of near-surface meteorological variables}

Under weak synoptic forcing with negligible advection, the temperature and moisture supply of the PBL is mainly determined by the components of the surface energy balance. We therefore compare time series of simulated and measured energy balance components at a valley site (Baden-Airpark, location of energy balance measurements of supersite R) and a mountain site (Hornisgrinde, supersite $\mathrm{H}$ ) in Figure 10. Even if the observed cell is comparably far away from these two measuring sites, the general ability of the models to correctly simulate the energy balance is important since, for example, large latent heat fluxes in the Rhine valley can provide the humidity supply for the mountain region by upslope and valley winds.

For the net radiation, a small time shift for the maximum values between measurements and simulations can be observed. This is due to the fact that surface measurements are $30 \mathrm{~min}$ averages whereas model data represent instantaneous values at the respective time step. At the valley site, maximum values of the models vary between 595 and $683 \mathrm{~W} \mathrm{~m}^{-2}$, and the measured maximum lies more or less in the middle of this range. After sunrise, the increase of the measured net radiation is slightly reduced, probably due to a shadowing effect of the nearby mountains to the east 


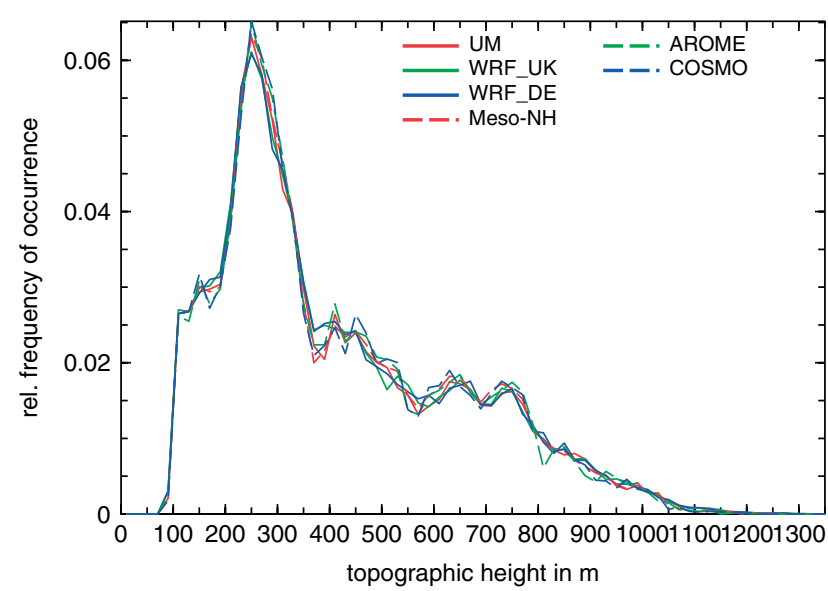

Figure 8. Frequency distributions of model topography height in the COPS domain. This figure is available in colour online at wileyonlinelibrary.com/journal/qj

of the station. At the mountain site of Hornisgrinde, most of the models overestimate the maximum net radiation values. WRF_UK has its maximum around $143 \mathrm{~W} \mathrm{~m}^{-2}$, larger than observed. Only the three COSMO configurations simulate the net radiation in good agreement with measurements. However, due to the simulation of some mid-level clouds in the morning hours, COSMO_IPA exhibits somewhat smaller values before noon. The sensible heat flux in the valley is rather well simulated by the UM, Méso-NH, and COSMO_DLR, whereas the maximum values simulated by WRF_UK, WRF_DE, COSMO_IPA and COSMO_IMK are considerably larger than the measured ones (over $200 \mathrm{~W} \mathrm{~m}^{-2}$ ). Consequently, the latent heat fluxes in these models show the smallest values. The remaining models are in comparatively good agreement with measurements. Most of the available energy at the ground (net radiation minus ground heat flux) is transported into latent heat as indicated by a Bowen ratio $\leq 1$. UM, Méso-NH, and COSMO_DLR simulate the distribution of available energy into sensible and latent heat in the daytime as observed. All remaining models, in particular COSMO_IMK, have a larger Bowen ratio. The sensible heat flux at the mountain site of Hornisgrinde is well simulated by most of the models. Only COSMO_IPA and $\mathrm{UM}$ simulate larger fluxes $\left(+125 \mathrm{~W} \mathrm{~m}^{-2}\right)$ around noon. As in the Rhine valley, most of the available energy is transferred into latent heat. UM and COSMO_IPA reveal the largest Bowen ratio in the daytime, and the remaining models show a rather good agreement with values around 0.6. The larger sensible heat fluxes at the mountain site are responsible for the higher Bowen ratios than the valley site.

The nearest surface observations are available from the site of Villingen-Schwenningen located approximately $25 \mathrm{~km}$ to the south of the convective storm (Figures 1 and 4). The comparison with these measurements shows that all models are too cold and too humid during the day (Figure 11). Temperature deviations due to different topographic heights between model and reality are negligible: assuming a dry adiabatic lapse rate, the maximum height difference of $38 \mathrm{~m}$ between model and real topography at this grid point results in a temperature difference of $0.37 \mathrm{~K}$ only. With a maximum difference of $20 \mathrm{~m}$ between the respective grid point heights of all models, the temperature difference is of no importance $(0.2 \mathrm{~K})$. COSMO_IPA and COSMO_IMK show the smallest bias of all models in the timeframe between 1100 and 1700 UTC. It is significant that the models with a reasonable good forecast of the convective storm (WRF_UK, Méso$\mathrm{NH}$, AROME) simulate a considerably lower maximum temperature $(-4.1$ to $-5.5 \mathrm{~K})$ and a higher relative humidity $(+21$ to $+34 \%)$. The aforementioned effect that AROME is warmer and drier than the other successful models is also obvious from this grid point analysis. A good agreement with observations is found for the simulated wind direction of all models. At least, the wind direction before CI (09001300 UTC) is well captured by all models.

\subsection{Boundary-layer profiles and convective indices}

For the formation and further evolution of deep convection, one controlling factor is the atmospheric density stratification. At first, the temperature and moisture conditions in the PBL, and the PBL height, are compared for a Rhine valley site (Achern, supersite $\mathrm{H}$ ) and a mountain site (AMF, supersite $\mathrm{M}$ ) in Figure 12. Here, the latest available radiosonde ascents before CI are used. At Achern, most of the models simulate lower PBL temperatures than observed. AROME simulates a slightly warmer $\mathrm{PBL}$, its height corresponding well with observations $(\approx 720 \mathrm{~m} \mathrm{agl})$. The UM temperatures in the mixed PBL agree well with the measured profile. However, the PBL height is twice as large. Also, WRF_DE simulates a deep PBL (1200 m agl) which probably is due to the choice of boundary-layer scheme (Yonsei) in which the countergradient term has effectively produced large eddies, and mixed the air too vigorously. The non-local PBL scheme in the UM could be the reason for the very deep PBL. The remaining models show lower PBL temperatures with $\mathrm{PBL}$ heights equal or lower than measured. It is worth noting that, for most of the PBL, specific humidity is simulated close to observations. Only COSMO_IPA and AROME have a $1.5 \mathrm{~g} \mathrm{~kg}^{-1}$ drier PBL in the Rhine valley. Larger differences between observations and the models are present at the AMF site. With the exception of AROME, all models simulate a colder PBL. Again, UM and WRF_DE overestimate the PBL height at around $1000 \mathrm{~m}$ agl. Despite the lower PBL heights with consequently smaller volumes of air into which the surface fluxes of moisture and heat are concentrated, the remaining models show significant lower PBL temperatures (up to $3.5 \mathrm{~K}$ ). Also, the simulated PBL moisture shows larger differences from the measurements: e.g. COSMO_DLR is over $3 \mathrm{~g} \mathrm{~kg}^{-1}$ too moist.

To analyze the conditions in the vicinity of the simulated convective cell, Figure 13 shows profiles of potential temperature and specific humidity from a grid point centred in the simulated precipitation areas $\left(8.42^{\circ} \mathrm{E}, 48.095^{\circ} \mathrm{N}\right)$ at 1400 UTC. Unfortunately, no measurements are available in this region to evaluate the model results. The same basic features regarding the height of the PBL are also simulated in the area of the precipitation site. Besides the large temperature $(3.5 \mathrm{~K})$ and humidity $\left(4 \mathrm{~g} \mathrm{~kg}^{-1}\right)$ differences between individual model results, it is again remarkable that the models which successfully reproduced the observed storm show different features. Méso-NH simulates the largest humidity values in the PBL with comparatively low temperatures and a mixing height of $1.2 \mathrm{~km}$ agl. On the other hand, AROME simulates a low PBL height of $400 \mathrm{~m}$ agl only, with humidity and temperature values lying approximately in the middle of the range of all simulations. WRF_UK has a higher PBL height of $900 \mathrm{~m}$ agl with temperatures close to the ones from Méso-NH and humidity values close to AROME. 
(a) 0000 UTC $\bullet 1400$ UTC

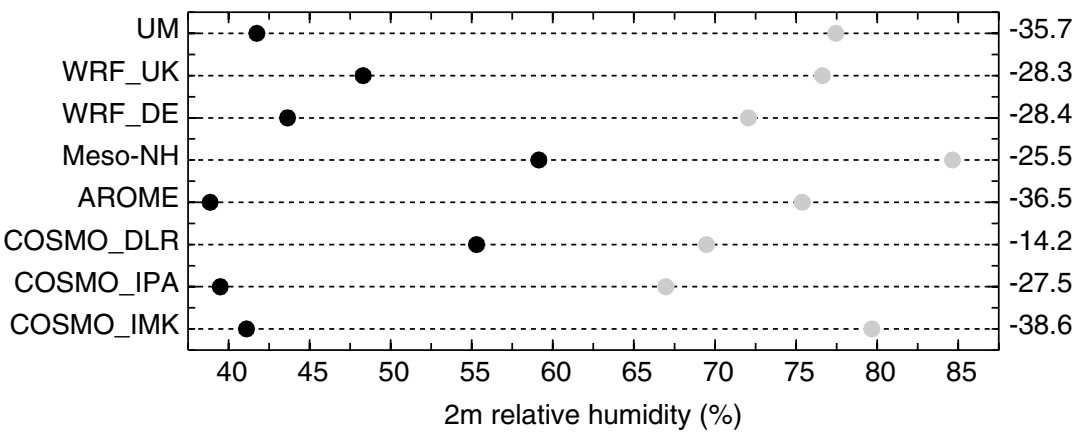

(b)

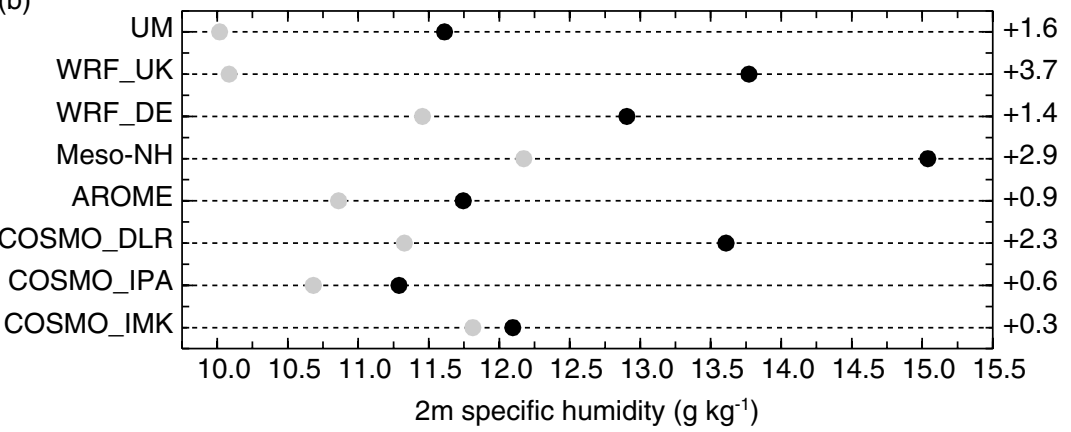

(c)

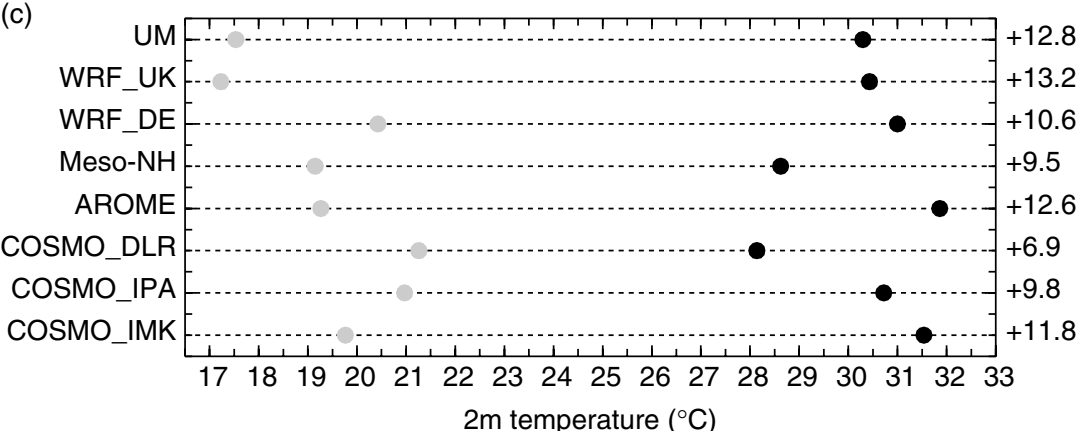

Figure 9. Mean values of (a) relative humidity, (b) specific humidity and (c) temperature for the full COPS domain as displayed in Figure 6. The differences between values for 0000 UTC and 1400 UTC are shown on the right-hand axes.

In order to analyze the potential of deep convection, some thermodynamic variables at the three grid points analyzed here are given in Table IV. With the exception of the UM, all simulated CAPE values are too low at Achern. The lowest CIN is simulated by WRF_DE with $39 \mathrm{~J} \mathrm{~kg}^{-1}$, whereas observations show a higher value of $106 \mathrm{~J} \mathrm{~kg}^{-1}$. Consequently, this model has one of the lowest LFC simulated. At the mountain site of Hornisgrinde, CAPE is smaller than in the Rhine valley. Only the UM and COSMO_DLR simulate a higher CAPE whereas COSMO_IMK shows a significantly lower value. All CIN values from the simulations are higher than the one from the radiosonde observation, but AROME and COSMO_DLR are very close to the observations. The grid point near VillingenSchwenningen shows that the successful models have CAPE values larger than $1000 \mathrm{~J} \mathrm{~kg}^{-1}$, with CIN less than $50 \mathrm{~J} \mathrm{~kg}^{-1}$. In particular, Méso-NH has the highest potential of deep convection: a low CIN value of $7 \mathrm{~J} \mathrm{~kg}^{-1}$ requires only a weak trigger mechanism to release the CAPE of $1544 \mathrm{~J} \mathrm{~kg}^{-1}$. The convective temperature is reached at this grid point from WRF_DE only, but the evolution of deep convection is suppressed due to only low amounts of CAPE. Similar to WRF_DE, COSMO_IMK simulates very low CIN values with only minimal amounts of CAPE. This is due to stable layers and/or inversions around $2 \mathrm{~km}$ agl where the lifted parcel again reaches the temperature of the ambient air leading to low heights of the equilibrium level (EL). The fact that convective inhibition from WRF_UK and COSMO_IPA are very similar, and only WRF_UK simulates a convective storm, indicates that the trigger mechanism required was not effective enough in the COSMO_IPA run. The overactive convection in the UM may be the product of an overly deep boundary layer, and reduced CIN, over the mountain areas. In addition, the dry and warm boundary layer near Villingen-Schwenningen results in a comparatively high LCL (Figure 13).

\subsection{Vertical distribution of moisture}

During COPS IOP $8 \mathrm{~b}$, the vertical humidity distribution was observed by means of an airborne lidar (differential absorption lidar LEANDRE 2) on board the SAFIRE (Service des Avions Français Instrumentés pour la Recherche en Environnement) Falcon 20. The west-east flight track along the geographical latitude $48.45^{\circ} \mathrm{N}$ at 1315 UTC was selected to compare the measured vertical distribution of moisture with the model results in the pre-convective environment. Measurements are available from 6.8 to $7.79^{\circ} \mathrm{E}$ covering the Vosges mountains approximately up to the river Rhine (Figure 14). UM, WRF_UK, and the three COSMO models 

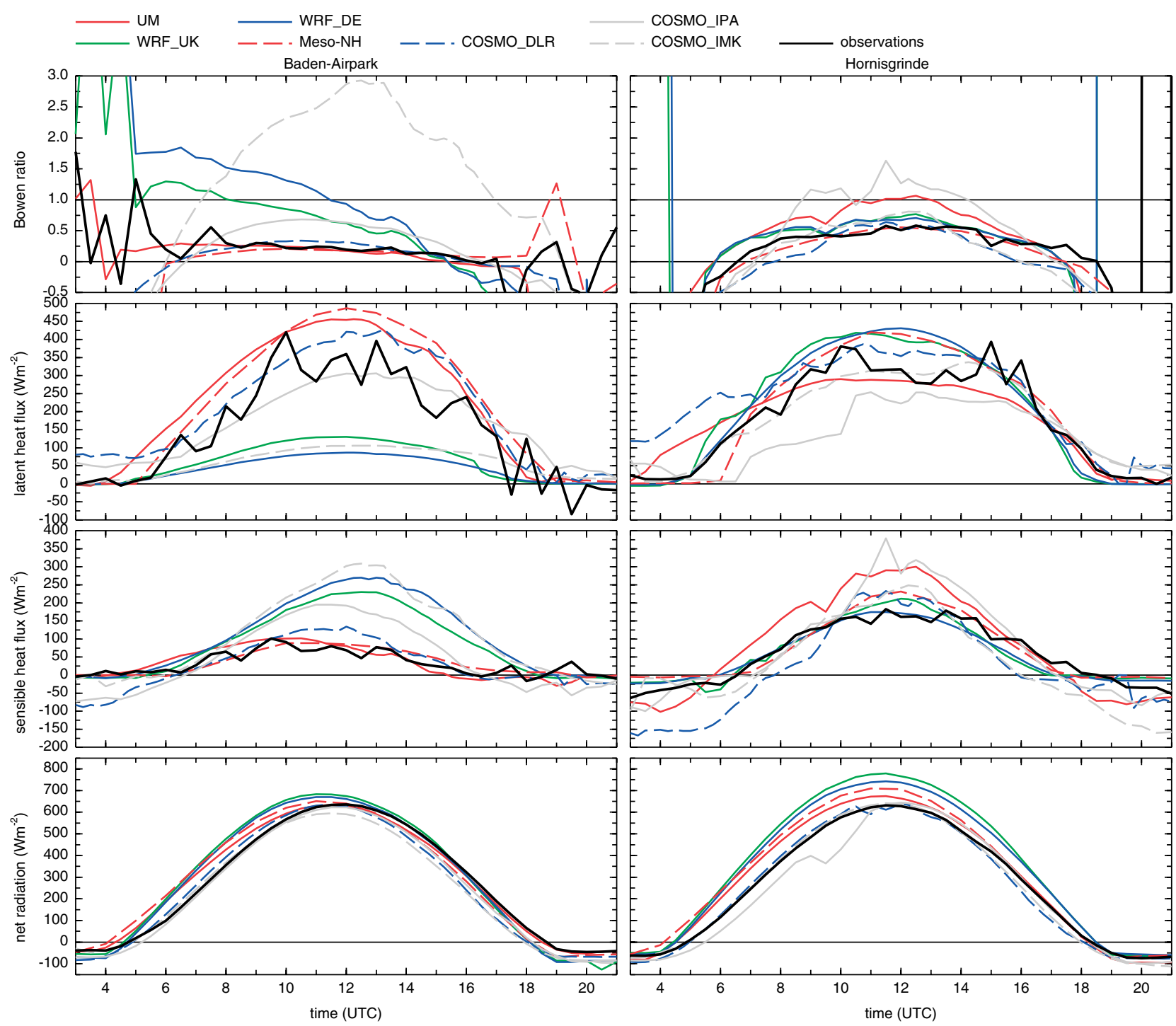

Figure 10. Time series of simulated and measured components of the surface energy balance for the Baden-Airpark (Rhine valley) and Hornisgrinde (top of northern Black Forest). Energy balance components from AROME were not available. This figure is available in colour online at wileyonlinelibrary.com/journal/qj

simulate the general distribution (high mixing ratios in the Rhine valley, lower ones over/west of the Vosges) reasonably well. WRF_DE shows high amounts of moisture already over the eastern part of the Vosges with decreasing values towards the Rhine valley. In contrast to this, Méso-NH and AROME simulate also higher humidity values in the western part of the Vosges. Besides the difference in the general distribution, the absolute values in the simulations differ from the measurements. Lidar measurements show values in the Rhine valley between 9 and $12 \mathrm{~g} \mathrm{~kg}^{-1}$, with individual spikes larger than $18 \mathrm{~g} \mathrm{~kg}^{-1}$. However, these small-scale humidity variations measured by lidar cannot be simulated, even by the model with the highest grid resolution (UM, $1 \mathrm{~km}$ ). When neglecting those small-scale extreme values, it can be stated that only WRF_DE simulates the mixing ratio with $10-11 \mathrm{~g} \mathrm{~kg}^{-1}$, close to observations. All the remaining models are too moist (12-13 $\mathrm{g} \mathrm{kg}^{-1}$ : Méso-NH, AROME, COSMO_IPA, COSMO_IMK; $13-14 \mathrm{~g} \mathrm{~kg}^{-1}$ : UM, WRF_UK; $14-15 \mathrm{~g} \mathrm{~kg}^{-1}$ : COSMO_DLR).

The maximum vertical extent of the $5 \mathrm{~g} \mathrm{~kg}^{-1}$ mixing ratio in the measurements is $3000 \mathrm{~m}$ amsl over the Vosges mountains. This is well reproduced by the UM, WRF_DE, and COSMO_IMK only. A lower vertical extent is simulated by WRF_UK $(2500 \mathrm{~m})$, AROME (2750 m), COSMO_DLR $(2600 \mathrm{~m})$ and COSMO_IPA $(2500 \mathrm{~m})$ whereas Méso-NH is the only model to overestimate the vertical extent by approximately $500 \mathrm{~m}$. With the exception of AROME, the humidity decrease towards the west is simulated by all models but with different strength; COSMO_DLR and COSMO_IMK show a strong horizontal humidity gradient towards the west comparable with the measured one. In contrast to this, the UM has only a small decrease of humidity towards the west, whereas AROME shows no decrease at all over the Vosges.

Even if no measurements are available over the Black Forest, the humidity distribution in the numerical simulations is of particular interest in this region because convection was initiated here. As is obvious from Figure 4, $\mathrm{CI}$ took place at a longitude of approximately $8.5^{\circ} \mathrm{E}$. The simulated mixing ratio at that longitude varies considerably between the individual model runs. WRF_UK, WRF_DE, Méso-NH, and COSMO_DLR simulate high amounts of humidity between 12 and $16 \mathrm{~g} \mathrm{~kg}^{-1}$. Results from the UM, AROME, COSMO_IPA, and COSMO_IMK show a drier 

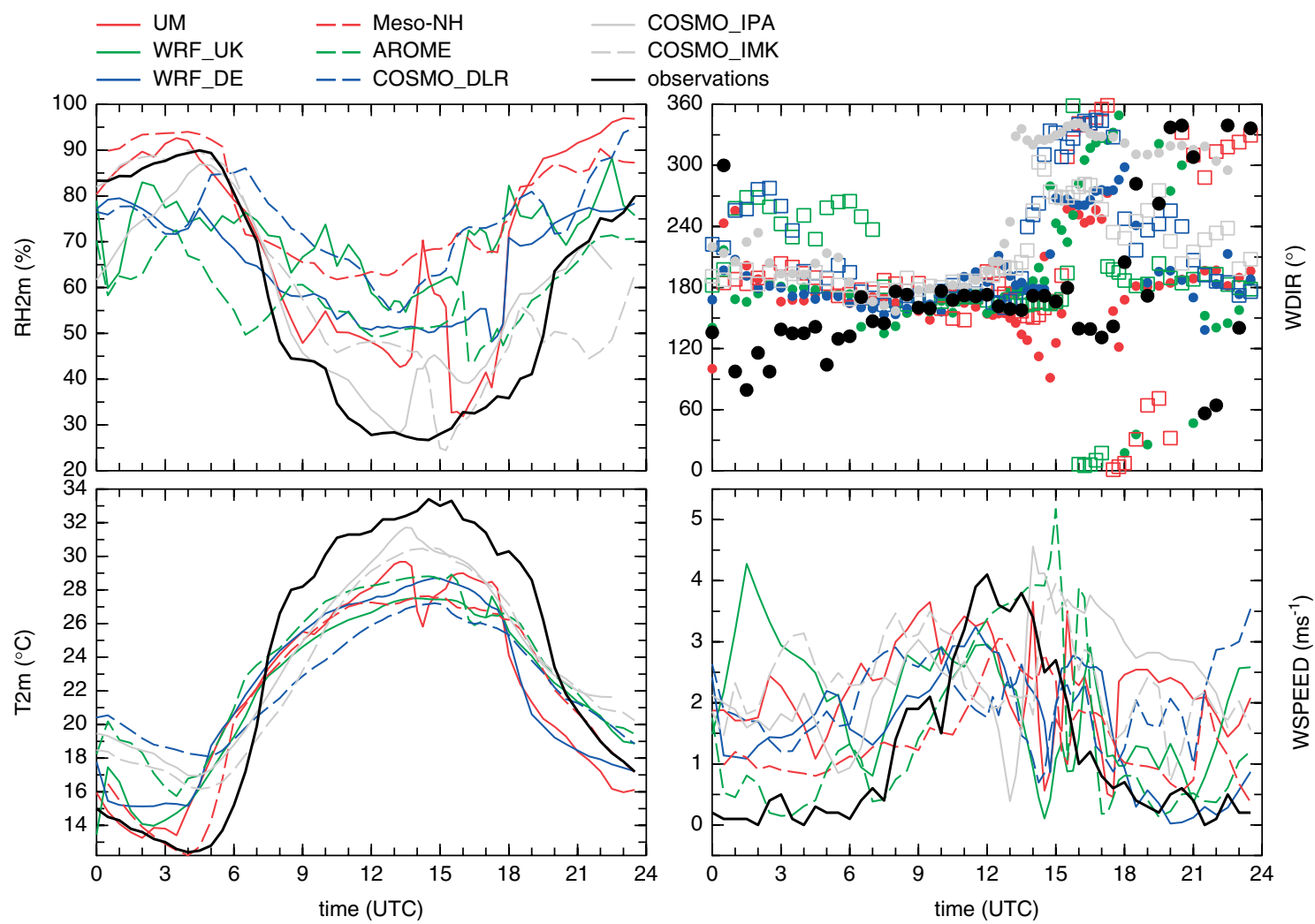

Figure 11. Measured and simulated near-surface meteorological variables at Villingen-Schwenningen. This figure is available in colour online at wileyonlinelibrary.com/journal/qj

Table IV. Thermodynamic variables at Achern (1400 UTC), the AMF Site (1130 UTC), and a grid point centred with respect to the precipitation areas simulated $\left(8.42^{\circ} \mathrm{E}, 48.095^{\circ} \mathrm{N}, 1400 \mathrm{UTC}\right)$ computed by lifting a parcel that reflects the mean values of temperature and moisture in the lowest $50 \mathrm{hPa}$.

\begin{tabular}{|c|c|c|c|c|c|c|c|c|c|}
\hline & Obs & UM & $\begin{array}{l}\text { WRF } \\
\text { _UK }\end{array}$ & $\begin{array}{l}\text { WRF } \\
\text { _DE }\end{array}$ & Méso-NH & AROME & $\begin{array}{c}\text { COSMO } \\
\text { _DLR }\end{array}$ & $\begin{array}{c}\text { COSMO } \\
\text { _IPA }\end{array}$ & $\begin{array}{c}\text { COSMO } \\
\text { _IMK }\end{array}$ \\
\hline \multicolumn{10}{|l|}{ Achern } \\
\hline $\mathrm{CAPE}^{a}$ & 1051 & 1282 & 711 & 903 & 684 & 664 & 659 & 352 & 652 \\
\hline $\mathrm{CIN}^{a}$ & 106 & 44 & 110 & 39 & 62 & 83 & 100 & 150 & 152 \\
\hline $\mathrm{LCL}^{b}$ & 1847 & 1846 & 1747 & 1875 & 1678 & 2218 & 1576 & 2018 & 1825 \\
\hline $\mathrm{LFC}^{b}$ & 2924 & 2743 & 3200 & 2838 & 3331 & 3249 & 3393 & 4086 & 3525 \\
\hline $\mathrm{EL}^{b}$ & 11701 & 11807 & 10808 & 11362 & 11152 & 11069 & 11892 & 10361 & 10532 \\
\hline \multicolumn{10}{|c|}{ AMF site } \\
\hline $\mathrm{CAPE}^{a}$ & 414 & 750 & 416 & 409 & 306 & 255 & 1135 & 426 & 73 \\
\hline $\mathrm{CIN}^{a}$ & 46 & 81 & 97 & 71 & 88 & 52 & 50 & 106 & 182 \\
\hline $\mathrm{LCL}^{b}$ & 2147 & 1901 & 1709 & 1853 & 1821 & 2333 & 1241 & 1840 & 1840 \\
\hline $\mathrm{LFC}^{b}$ & 2717 & 3086 & 3055 & 3187 & 3526 & 3222 & 2646 & 3353 & 3558 \\
\hline $\mathrm{EL}^{b}$ & 10215 & 11459 & 10169 & 10110 & 10050 & 9788 & 11488 & 10128 & 7463 \\
\hline \multicolumn{10}{|c|}{ Centre of simulated precipitation } \\
\hline $\mathrm{CAPE}^{a}$ & - & 422 & 1060 & 4 & 1544 & 1010 & 1192 & 1379 & 0.2 \\
\hline $\mathrm{CIN}^{a}$ & - & 26 & 46 & 0 & 7 & 33 & 88 & 50 & 8 \\
\hline $\mathrm{LCL}^{b}$ & - & 2257 & 1419 & 1596 & 1220 & 1662 & 1094 & 1548 & 1500 \\
\hline $\mathrm{LFC}^{b}$ & - & 3303 & 2337 & 1596 & 1988 & 2424 & 2494 & 2522 & 1832 \\
\hline $\mathrm{EL}^{b}$ & - & 10528 & 10669 & 2420 & 11738 & 10889 & 11101 & 11080 & 1927 \\
\hline
\end{tabular}

Units: ${ }^{a} \mathrm{~J} \mathrm{~kg}^{-1} ;{ }^{b} \mathrm{~m}$ agl. 


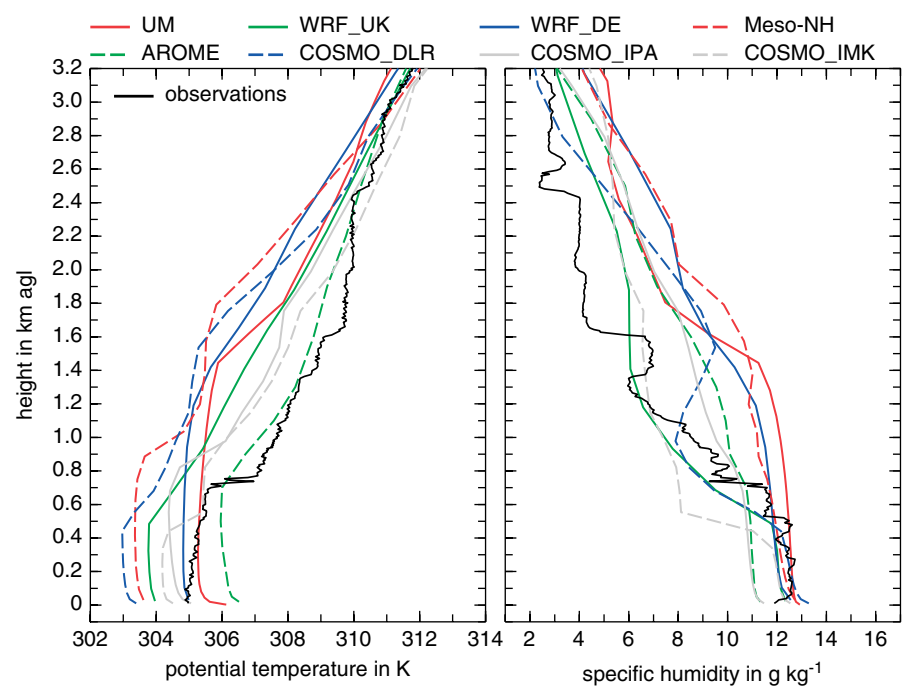

(a) Achern 1400 UTC

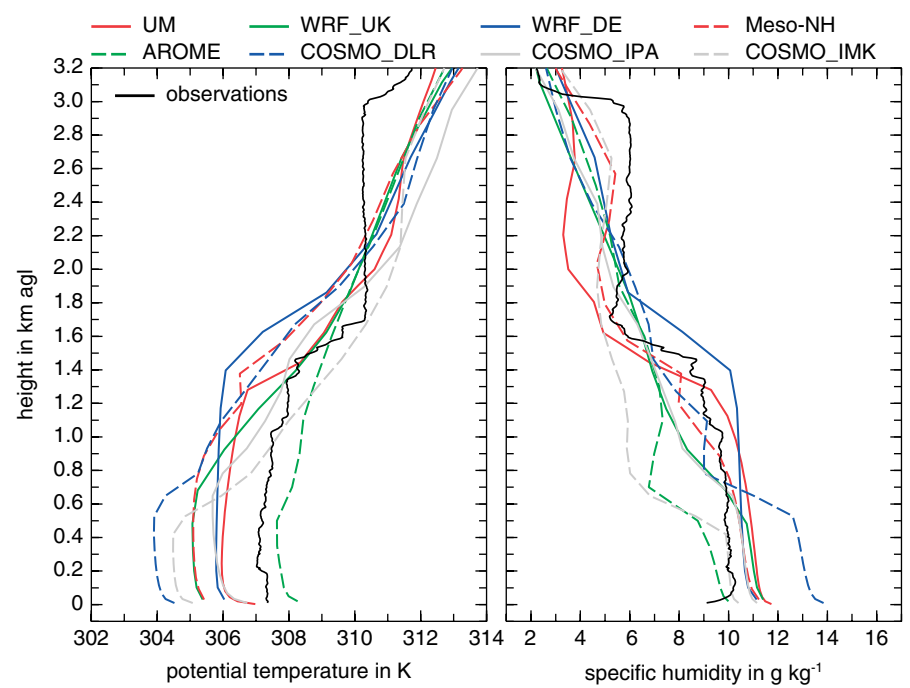

(b) AMF 1130 UTC

Figure 12. Boundary-layer profiles of (a) potential temperature and specific humidity at Achern (Rhine valley) at 1400 UTC. (b) is the same as (a) but for the AMF Site (northern Black Forest) at 1130 UTC. This figure is available in colour online at wileyonlinelibrary.com/journal/qj

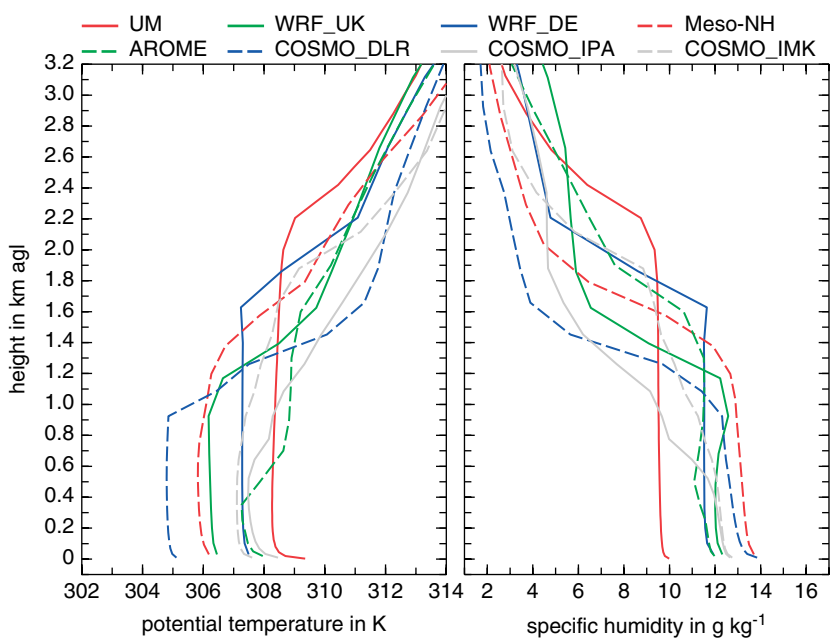

Figure 13. Boundary-layer profiles of (a) potential temperature and (b) specific humidity from a grid point near Villingen-Schwenningen $\left(8.42^{\circ} \mathrm{E}\right.$, $48.095^{\circ} \mathrm{N}$ ) at $1400 \mathrm{UTC}$. This figure is available in colour online at wileyonlinelibrary.com/journal/qj 

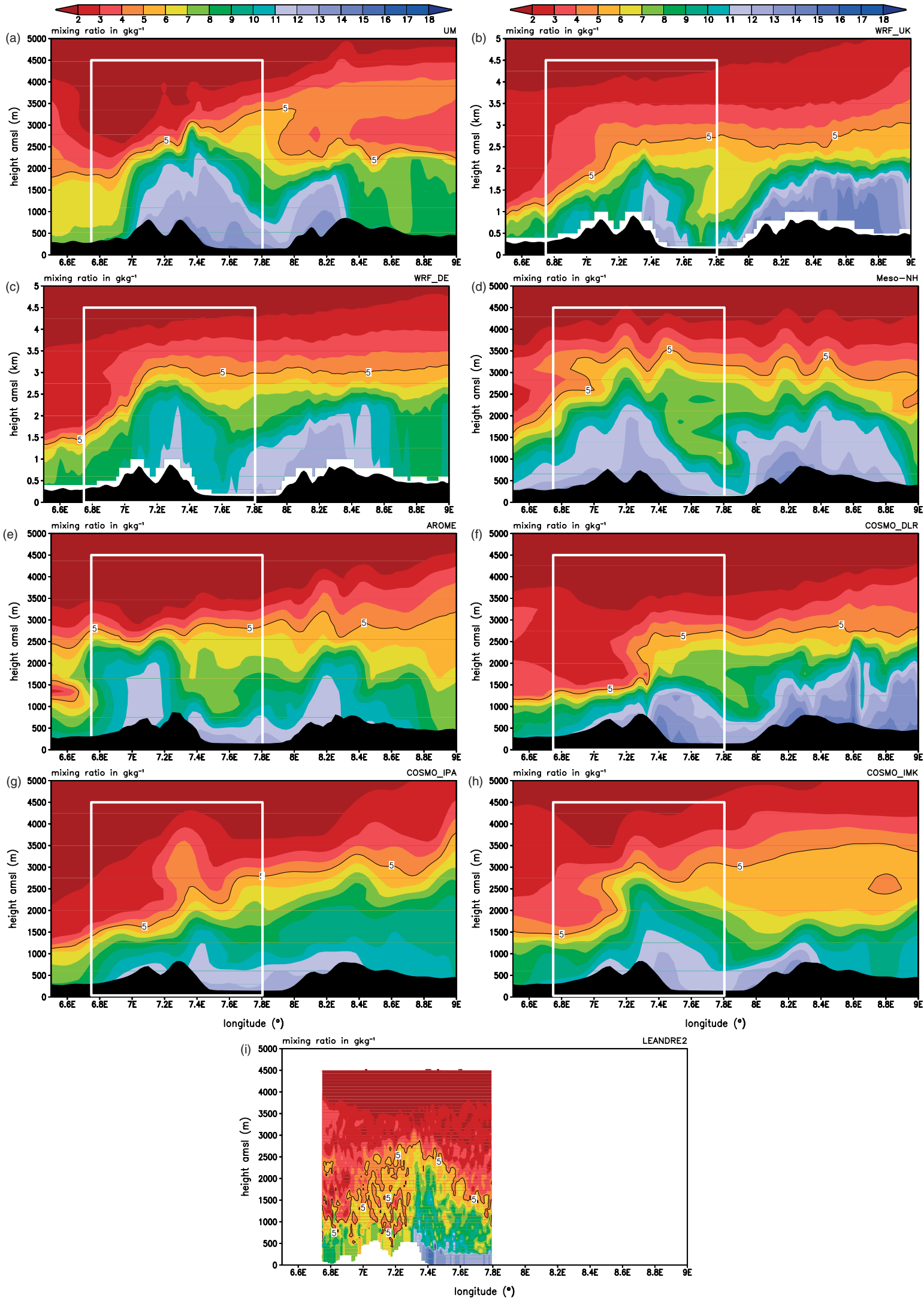

Figure 14. Vertical cross-sections of mixing ratio along the west-east flight track shown in Figure 1 from models (a) UM, (b) WRF_UK, (c) WRF_DE, (d) Méso-NH, (e) AROME, (f) COSMO_DLR, (g) COSMO_IPA and (h) COSMO_IMK. White boxes indicate the region of lidar measurements conducted with LEANDRE 2 at 1315 UTC, and shown in (i). The lowest $500 \mathrm{~m}$ of the measured data have to be neglected due to measurement uncertainties close to the orography. This figure is available in colour online at wileyonlinelibrary.com/journal/qj 

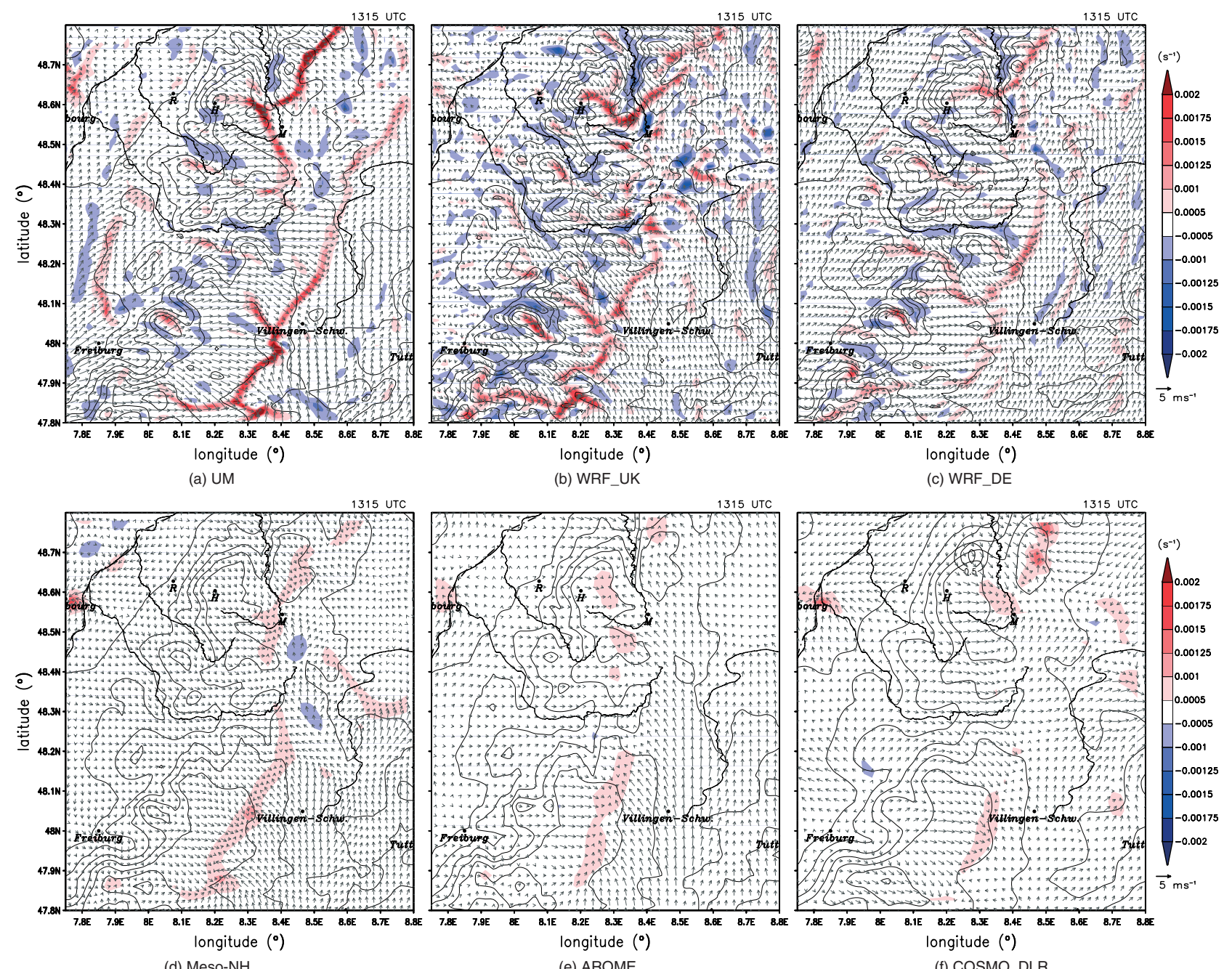

(d) Meso-NH

(e) AROME

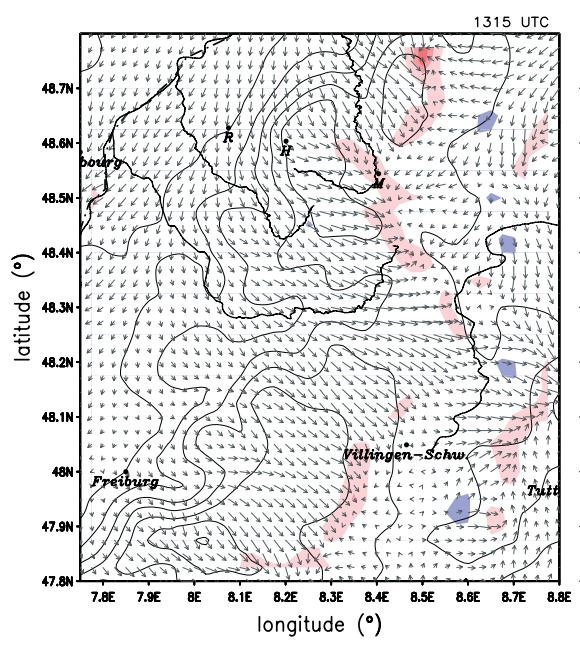

(g) COSMO_IPA

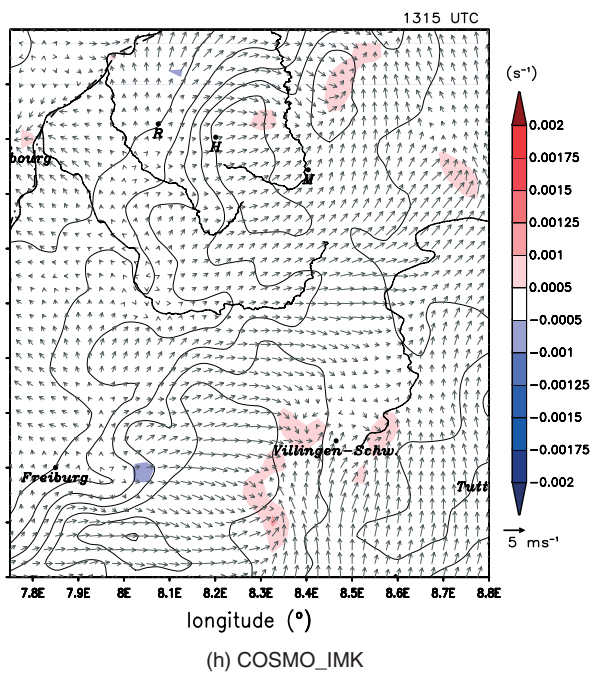

Figure 15. Near-surface horizontal wind field (arrows) and convergence (colour shading) at 1315 UTC from models (a) UM, (b) WRF_UK, (c) WRF_DE, (d) Méso-NH, (e) AROME, (f) COSMO_DLR, (g) COSMO_IPA and (h) COSMO_IMK. In (a), only alternate wind arrows in both directions are plotted, and in (b) and (c) only alternate wind arrows in the latitude direction. The arrow densities of the remaining models correspond to their respective grid resolutions. This figure is available in colour online at wileyonlinelibrary.com/journal/qj

boundary layer with values ranging between 8 and $11 \mathrm{~g} \mathrm{~kg}^{-1}$. The height of the $5 \mathrm{~g} \mathrm{~kg}^{-1}$ isoline varies only between 2500 and $3000 \mathrm{~m}$ amsl. As a consequence, high humidity amounts in the lower parts of the PBL lead to a strong vertical humidity gradient (WRF_UK or COSMO_DLR). Furthermore, the humid air from the Rhine valley in some model configurations (UM, AROME, COSMO_IPA,
COSMO_IMK) just reaches the maximum elevation of the Black Forest whereas the other models have also higher amounts of humidity east of the Black Forest crest. This indicates that, besides moisture transport by thermally induced upslope and valley winds, advective processes and/or local evaporation must have played a role in the results of e.g. WRF_UK, Méso-NH, and COSMO_DLR. 


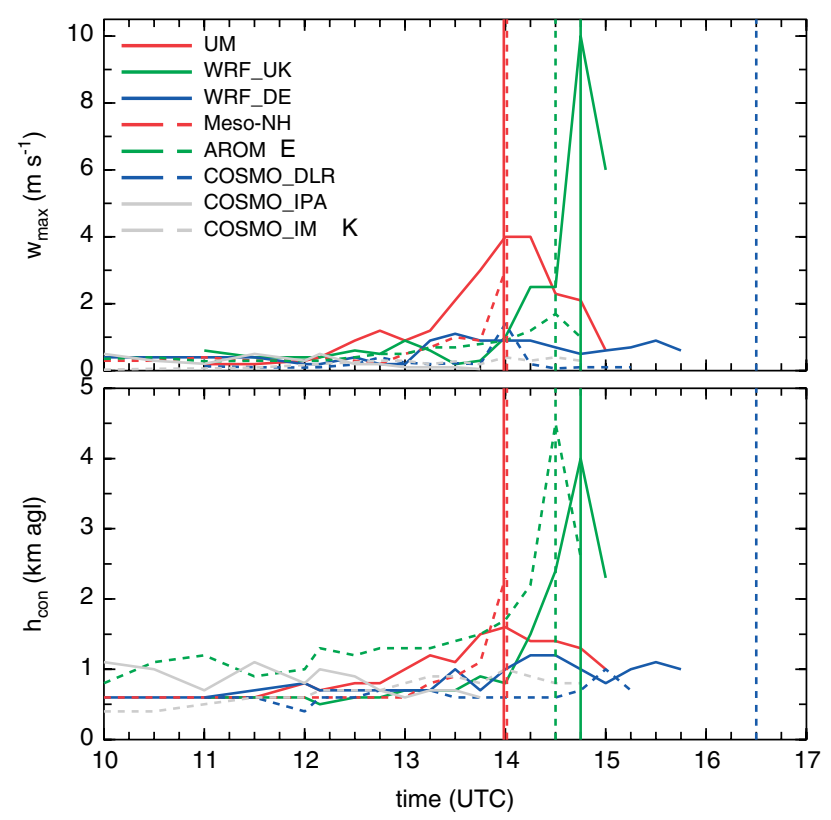

Figure 16. (a) maximum vertical velocity $\mathrm{w}_{\max }$ and (b) associated height of low-level convergence above ground $\mathrm{h}_{\mathrm{con}}$, for the various models. Vertical straight lines indicate the times when the first precipitation was simulated. This figure is available in colour online at wileyonlinelibrary.com/journal/qj

\subsection{Low-level convergence}

As already mentioned in section 3, the strong spatial correlation of the observed low-level convergence with subsequent cloud formation strongly suggests that lifting along a convergence line was the key trigger mechanism of the thunderstorm on that day. Radar observations indicated a convergence zone northeast of Freiburg reaching to the Kinzig valley which moved slowly towards the east (Barthlott et al., 2010). It is therefore of special interest to examine not only the existence, but also the strength and the induced lifting, of this convergence line in the numerical simulations. The results show that all models simulate a roughly north-south oriented convergence line west of Villingen-Schwenningen in the near-surface wind field (Figure 15). The strength of the convergence, however, differs significantly between the individual model results. The strongest convergence is simulated by the UM and WRF_UK followed by WRF_DE. Méso-NH, AROME, and the three COSMO models have more or less similar maximum convergence values which are lower than the aforementioned models. It must be stated that the convergence strength does not depend solely on the respective grid resolution: a higher number of grid points does not affect the convergence, assuming a constant horizontal wind gradient. A higher grid resolution, however, allows for a more detailed representation of the flow structure and leads therefore mostly also to a higher convergence. In addition to the varying strength, the length of the convergence line is different from model to model: the UM simulates a convergence line throughout the whole displayed range with maximum convergence in the southern part west of Villingen-Schwenningen. The two WRF configurations simulate an almost connected line up to a latitude of $48.4^{\circ} \mathrm{N}$. One reason for the slight differences in strength and structure of the low-level convergence between the two WRF configurations is probably the use of different $\mathrm{PBL}$ schemes (section 2). Méso-NH shows a convergence just up to the Kinzig valley whereas AROME and the three COSMO runs reveal a smaller area of convergence. The reason for the convergence simulated seems to be the same for all participating models: southerly winds between the southern Black Forest and the Swabian Jura encounter westerly/northwesterly winds from the region of the Kinzig valley and the northern part of the southern Black Forest, probably as a result of a flow around the mountain. Over the crest of the northern Black Forest, all models simulate a more or less distinct convergence line due to thermally induced circulation systems in the morning hours (not shown). Later on, this convergence line moves in eastward direction in agreement with experimental findings of Kalthoff et al. (2009). This northern convergence line, however, is beyond the scope of the present study.

Besides the existence of convergence lines, their vertical extent and the associated maximum vertical velocity is of particular interest. Therefore, these parameters were extracted from vertical cross-sections of horizontal convergence and vertical wind speed at the latitude at which each model simulates its maximum convergence (UM: $48^{\circ} \mathrm{N}$, WRF_UK: $47.975^{\circ} \mathrm{N}$, WRF_DE: $48.1^{\circ} \mathrm{N}$, Méso$\mathrm{NH}: 48.025^{\circ} \mathrm{N}, \mathrm{AROME}: 48.125^{\circ} \mathrm{N}, \mathrm{COSMO} D L R: 48.05^{\circ} \mathrm{N}$, COSMO_IPA: $48.1^{\circ} \mathrm{N}$, COSMO_IMK: $\left.48.05^{\circ} \mathrm{N}\right)$. The time series in Figure 16 reveal that all models simulate a convergence line after 1000 UTC. The height of the individual convergent area $h_{\text {con }}$ (where convergence is larger than 0) varies between 450 and $1100 \mathrm{~m}$ agl before noon. AROME and COSMO_IPA show the largest vertical extent, but vertical velocities are still rather low (less than $0.5 \mathrm{~m} \mathrm{~s}^{-1}$ ). Although COSMO_IPA shows a decreasing height of the convergent area and that from COSMO_DLR remains more or less constant, the remaining models simulate an increase of $h_{\text {con }}$ after 1200 UTC. Simultaneously, the vertical wind speeds become stronger. Vertical wind speeds larger than $2 \mathrm{~m} \mathrm{~s}^{-1}$ are simulated by the UM, WRF_UK, Méso-NH, and AROME. The strongest updraughts are simulated by WRF_UK with values larger than $10 \mathrm{~m} \mathrm{~s}^{-1}$. Aircraft measurements performed with the Dornier 128 on a flight level of $1500 \mathrm{~m}$ amsl between 1317 and 1328 UTC revealed updraughts of about $3.5 \mathrm{~m} \mathrm{~s}^{-1}$ below individual cells in the convergence zone north of Freudenstadt. The models with deep convection in that area simulate roughly similar values between $1.7 \mathrm{~m} \mathrm{~s}^{-1}$ (AROME) and $4 \mathrm{~m} \mathrm{~s}^{-1}$ (UM). It is worth noting that the AROME model simulates comparatively low vertical wind speeds, but the vertical extent of the updraughts $(4.5 \mathrm{~km} \mathrm{agl})$ is the highest value of all simulations. The decisive role of convergence-induced lifting for convection initiation is also manifested by the onset of convective precipitation in the simulations: UM, WRF_UK, Méso-NH, and AROME simulate convective precipitation at the time when $h_{\text {con }}$ is highest and the largest vertical wind speeds are simulated.

\section{Discussion}

Due to the absence of relevant synoptic forcing, deep convection on 15 July 2007 must have been initiated by local processes related to the orography in the planetary boundary layer. The role of the orography can be specified by thermal effects due to differential heating of the Earth's surface leading to slope and valley winds. This is a prerequesite of mass convergence and associated lifting. Dynamical influences (such as blocking or leeside effects) 
are evident -at least for some of the models -where the simulated convergence line is fostered by a flow around the mountain. The measurements performed on that day indicated that deep convection was triggered by updraughts penetrating the PBL-capping inversion up to the LFC as a result of low-level convergence, although CAPE was only moderate and CIN was high. The present intercomparison of the performance of eight model configurations of five convection-resolving models revealed large differences between individual model results. There was considerable variation, not only in the successful reproduction of the observed convective storm, but also in the near-surface meteorological variables as well as the vertical temperature and humidity distributions. The variety of the numerical findings is a result of the different configurations (horizontal and vertical grid resolution, physical schemes, etc.) as well as different initial and boundary conditions. As a consequence, the determination of the reasons for the different model results remains difficult, if not impossible. However, each model configuration is representative of that model as a whole and represents typical configurations currently used. Additionally, examining all the degrees of freedom in each model would be exhaustive and beyond the scope of this study.

The numerical results show that WRF_UK, Méso-NH, and AROME are the only models to simulate reasonably well the convective activity of the analysed day. The UM overestimates convective precipitation in other domains of the COPS area and produces too long-lasting precipitation in the area of the main cell. COSMO_DLR simulates a comparatively small amount of rain in the south of the area of the main cell, but also overestimates convective precipitation in other regions. Finally, WRF_DE, COSMO_IPA, and COSMO_IMK did not simulate convective precipitation larger than $0.5 \mathrm{~mm}$.

The comparison with measurements was performed with components of the surface energy balance, nearsurface meteorological variables, boundary-layer profiles, convective indices, and airborne lidar measurements of humidity. The successful models seem to have somewhat different mechanisms for initiation of deep convection: whereas Méso-NH reveals a comparatively humid PBL, thermal forcing seems to be more important for CI in the AROME run. The analysis of convective indices near the initiation point revealed that the best realisations all share a combination of high CAPE and modest CIN. It is worth noting that all models are capable of reproducing the convergence line observed by radar. However, the line's strength and potential to lift air varies considerably between individual model results. A common feature of the successful models is that they have the largest vertical extent of lowlevel convergence $(2.3-4.5 \mathrm{~km}$ agl) and also the highest vertical wind speeds induced by lifting along their respective convergence line. A deficiency of the remaining simulations is therefore the strength and lifting capabilities of PBL convergence lines.

These results suggest that, besides an accurate specification of the thermodynamic and kinematic fields, low-level convergence lines and their ability to lift parcels up to the LFC need to be well represented in NWP models in order to account for their triggering effects of deep moist convection and to improve the overall forecast skill. The fact that a reasonably good representation of the convective storm was partly caused for the wrong reasons (e.g. a too moist PBL of Méso-NH) is of particular importance and highlights the benefits of having an ensemble of models for operational weather forecasting.

We like to point out again that a single case-study cannot be used to conduct a systematic model evaluation. Hence, the poor performance of some models on that day is not necessarily a reflection of the models themselves. Moreover, this study demonstrates how widely the model results can differ and that sensitivity tests for each model are needed for the decision to use a certain model for a certain application.

\section{Acknowledgements}

This study was financed by DFG research grant BA 3810/1-1. The authors wish to thank the Deutsche Forschungsgemeinschaft (DFG) for funding the Priority Programme SPP 1167, in which COPS was embedded. We also thank the Deutscher Wetterdienst (DWD) for providing radar images, the COSMO model code as well as initial and boundary data. Meteosat-8 Rapid Scans were kindly provided by the European Organisation for the Exploitation of Meteorological Satellites (EUMETSAT). We are also grateful to the Atmospheric Radiation Measurement (ARM) Program for operating the ARM Mobile Facility. The French contribution was supported by the Centre National d'Etudes Spatiales (CNES), Agence Nationale de la Recherche (ANR, project COPS-France), Institut Nationale des Sciences de l'Univers (INSU, programme LEFE), and Météo-France. The UK contribution was supported by the Natural Environment Research Council.

\section{References}

Aoshima F, Behrendt A, Bauer H-S, Wulfmeyer V. 2008. Statistics of convection initiation by use of Meteosat rapid scanning data during the Convective and Orographically-induced Precipitation Study (COPS). Meteorol. Z. 17: 921-930.

Barthlott C, Corsmeier U, Meissner C, Braun F, Kottmeier C. 2006. The influence of mesoscale circulation systems on triggering convective cells over complex terrain. Atmos. Res. 81: 150-175.

Barthlott C, Schipper JW, Kalthoff N, Adler B, Kottmeier C, Blyth A, Mobbs S. 2010. Model representation of boundary-layer convergence triggering deep convection over complex terrain: A case-study from COPS. Atmos. Res. 95: 172-185 DOI:10.1016/j.atmosres.2009.02.010.

Behrendt A, Pal S, Aoshima F, Bender M, Blyth A, Corsmeier U, Cuesta J, Dick G, Dorninger M, Flamant C, Di Girolamo P, Gorgas T, Huang Y, Kalthoff N, Khodayar S, Mannstein H, Träumner K, Wieser A, Wulfmeyer V. 2011. Observation of convection initiation processes with a suite of state-of-the-art research instruments during COPS IOP 8b. Q. J. R. Meteorol. Soc. 137(S1): 81-100 DOI: 10.1002/qj.758.

Bott A. 1989. A positive definite advection scheme obtained by nonlinear renormalization of the advective fluxes. Mon. Weather Rev. 117: $1006-1015$

Bouttier F. 2009. 'AROME system documentation'. Météo-France: Toulouse, France. Available at http://www.cnrm.meteo.fr/arome/ docintro.html

Buzzi M. 2008. 'Challenges in operational numerical weather prediction at high resolution in complex terrain'. DSc thesis. ETH: Zurich, Switzerland. DOI: 10.3929/ethz-a-005698833. http://ecollection.ethbib.ethz.ch/view/eth:30923.

Byers HR, Rodebush HR. 1948. Causes of thunderstorms of the Florida peninsula. J. Meteorol. 5: 275-280.

Chaboureau J-P, Guichard F, Redelsperger J-L, Lafore J-L. 2004. The role of stability and moisture in the diurnal cycle of convection over land. Q. J. R. Meteorol. Soc. 130: 3105-3117.

Davies T, Cullen MJP, Malcolm AJ, Mawson MH, Staniforth A, White AA, Wood N. 2005. A new dynamical core for the Met Office's global and regional modelling of the atmosphere. Q. J. R. Meteorol. Soc. 131: 1759-1782 DOI:10.1256/qj.04.101.

Kalthoff N, Adler B, Barthlott C, Corsmeier U, Mobbs S, Crewell S, Träumner K, Kottmeier C, Wieser A, Smith V. 2009. 
The impact of convergence zones on the initiation of deep convection: A case study from COPS. Atmos. Res. 93: 680-694 DOI:10.1016/j.atmosres.2009.02.010.

Keil C, Craig GC. 2009. A displacement and amplitude score employing an optimal flow technique. Weather Forecast. 24: 1297-1308.

Kossmann M, Fiedler F. 2000. Diurnal momentum budget analysis of thermally induced slope winds. Meteorol. Atmos. Phys. 75: 195-215.

Kottmeier C, Kalthoff N, Barthlott C, Corsmeier U, Van Baelen J, Behrendt A, Behrendt R, Blyth A, Coulter R, Crewell S, Di Girolamo P, Dorninger M, Flamant C, Foken T, Hagen M, Hauck C, Höller H, Konow H, Kunz M, Mahlke H, Mobbs S, Richard E, Steinacker R, Weckwerth T, Wieser A, Wulfmeyer V. 2008. Mechanisms initiating deep convection over complex terrain during COPS. Meteorol. Z. 17: 931-948.

Lafore J-P, Stein J, Asencio N, Bougeault P, Ducrocq V, Duron J, Fischer C, Héreil P, Mascart P, Masson V, Pinty J-P, Redelsperger J-L, Richard E, Vilà-Guerau de Arellano J. 1998. The Meso-NH Atmospheric Simulation System. Part I: Adiabatic formulation and control simulations. Scientific objectives and experimental design. Ann. Geophys. 16: 90-109.

Molteni F, Buzzi R, Marsigli C, Montani A, Nerozzi F, Paccagnella T. 2001. A strategy for high-resolution ensemble prediction. I: Definition of representative members and global-model experiments. Q. J. R. Meteorol. Soc. 127: 2069-2094.

Müller MD, Scherer D. 2005. A grid- and subgrid-scale radiation parameterization of topographic effects for mesoscale weather forecast models. Mon. Weather Rev. 133: 1431-1442.

Orville HD. 1965. A numerical study of the initiation of cumulus clouds over mountainous terrain. J. Atmos. Sci. 22: 684-699.

Raymond DJ, Wilkening MH. 1980. Mountain-induced convection under fair weather conditions. J. Atmos. Sci. 37: 2693-2700.

Richard E, Chaboureau JP, Flamant C, Champollion C, Hagen M, Schmidt K, Kiemle C, Corsmeier U, Barthlott C, Di Girolamo P. 2011. Forecasting summer convection over the Black Forest: a casestudy from the Convective and Orographically-induced Precipitation Study (COPS) experiment. Q. J. R. Meteorol. Soc., 137(S1): 101-117, DOI: $10.1002 / q j .710$.

Schättler U, Doms G, Schraff C. 2009. 'A description of the nonhydrostatic regional COSMO-Model, Part VII: User's Guide’. Available at http://www.cosmo-model.org.

Schwitalla T, Bauer H-S, Wulfmeyer V, Zängl G. 2008. Systematic errors of QPF in low-mountain regions as revealed by MM5 simulations. Meteorol. Z. 17: 903-919.
Skamarock WC, Klemp JB, Dudhia J, Gill DO, Barker DM, Duda MG Huang X-Y, Wang W, Powers JG. 2008. 'A description of the Advanced Research WRF version 3'. Tech. Note TN-475+STR. NCAR: Boulder, USA.

Stensrud DJ, Bao J-W, Warner TT. 2000. Using initial condition and model physics perturbations in short-range ensemble simulations of mesoscale convective systems. Mon. Weather Rev. 128: 2077-2107.

Trentmann J, Keil C, Salzmann M, Barthlott C, Bauer H-S, Lawrence M, Leuenberger D, Wernli H, Wulfmeyer V, Corsmeier U, Kottmeier C. 2009. Multi-model simulations of a convective situation in lowmountain terrain in central Europe. Meteorol. Atmos. Phys. 103: 95-103. DOI: 10.1007/s00703-008-0323-6.

Weisman ML, Davis C, Wang W, Manning KW, Klemp JB. 2008.. Experiences with 0-36-h explicit convective forecasts with the WRFARW model. Weather Forecast. 23: 407-437.

Wilson DR, Ballard SP. 1999. A microphysically based precipitation scheme for the UK Meteorological Office Unified Model. Q. J. R. Meteorol. Soc. 125: 1607-1636.

Wilson JW, Schreiber WE. 1986. Initiation of convective storms at radarobserved boundary-layer convergence lines. Mon. Weather Rev. 114: 2516-2536.

Wulfmeyer V, Behrendt A, Bauer H-S, Kottmeier C, Corsmeier U, Blyth A, Craig G, Schumann U, Hagen M, Crewell S, Di Girolamo P, Flamant C, Miller M, Montani A, Mobbs S, Richard E, Rotach M, Arpagaus M, Russchenberg H, Schlüssel P, König M, Gärtner V, Steinacker R, Dorninger M, Turner D, Weckwerth T, Hense A, Simmer C. 2008. The Convective and Orographically-induced Precipitation Study: A research and development project of the World Weather Research Program for improving quantitative precipitation forecasting in low-mountain regions. Bull. Amer. Meteorol. Soc. 89: 1477-1486.

Wulfmeyer V, Behrendt A, Kottmeier C, Corsmeier U, Barthlott C, Craig GC, Hagen M, Althausen D, Aoshima F, Arpagaus M, Bauer H-S, Bennett L, Blyth A, Brandau C, Champollion C, Crewell S, Dick G, Di Girolamo P, Dorninger M, Dufournet Y, Eigenmann R, Engelmann R, Flamant C, Foken T, Gorgas T, Grzeschik M, Handwerker J, Hauck C, Höller H, Junkermann W, Kalthoff N, Kiemle C, Klink S, König M, Krauss L, Long CN, Madonna F, Mobbs S, Neininger B, Pal S, Peters G, Pigeon G, Richard E, Rotach MW, Russchenberg H, Schwitalla T, Smith V, Steinacker R, Trentmann J, Turner DD, van Baelen J, Vogt S, Volkert H, Weckwerth T, Wernli H, Wieser A, Wirth M. 2011. The Convective and Orographically-induced Precipitation Study (COPS): The scientific strategy, the field phase, and research highlights. Q. J. R. Meteorol. Soc. 137(S1): 31-41, DOI: 10.1002/qj.752. 